واكاوى جامعه شناختى شرايط زنان در عربستان سعودى

(مورد مطالعه: رمان بنات الرياض اثر رجاء عبدالله الصانع)

دكتر على افضلى

استاديار گروه زبان و ادبيات عربى، دانشخاه تهران

Ali.afzali@ut.ac.ir

دكتر رحيم عتابى

استاديار گروه زبان وادبيات فارسى، دانشخاه بغداد

\title{
drraheem2004@ colang.uobaghdad.edu.iq
}

\section{معصومه محسنى مهر (سكوند)}

كارشناس ارشد زبان وادبيات عربى، دانشخاه آزاد اسلامى واحد دزفول

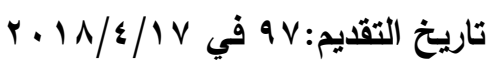

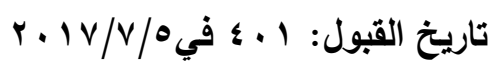

جكيده:

جامعهشناختى ادبيات يكى از شيوههاى نسبتاً نوين در مطالعات ادبى است. آنجه در اين نقد از اهميّت بيشترى برخوردار است، انعكاس تصوير جامعه در جهان تخيلى و ادبى و شكل هاى مختلف آن است. رمان

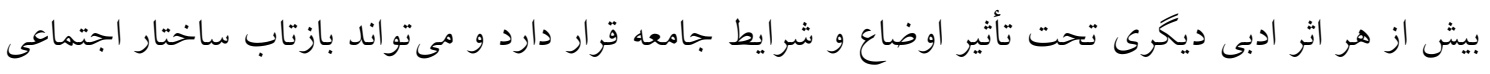
جامعه باشد. رمان بنات الرياض اثر رجاء الصانع، داستاننويس معاصر عربستانى، اثرى واقع گر ايانه به شمار مىرود كه وقايع آن، در بردارندهى تجربيات و شواهد عينى زندكى نويسنده، نسبت به مسائل زنان عربستان

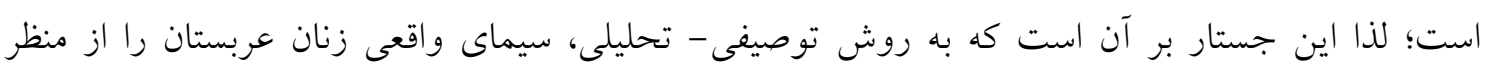

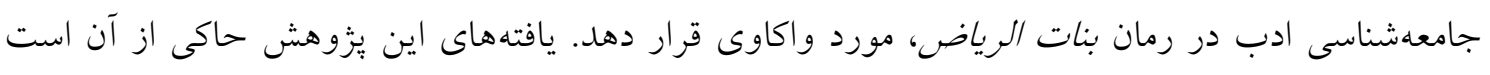

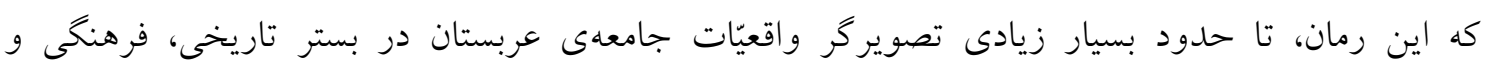
اجتماعى است. رجاء الصانع در رمان بنات الرياض با زبانى نمادين به نقد اوضاع اجتماعى و فرهنكى زئى زنان جامعه عربستان يرداخته و علاوه بر نشان دادن بحران روحى شخصيتهاى زن داستان، نمادى از مشكلات جامعهى عربستان، شرح مصيبتهاى زنان در اين كشور و تعارض هاى درونى آنان را به تصوير كشيده است.

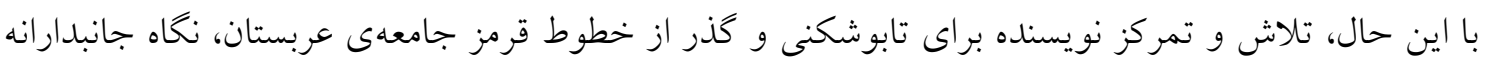
و بعضاً غير منطقى او را به همراه داشته است. كليدوازهها: رمان معاصر عربى، خوانش جامعهشناختى، رجاء الصانع، بنات الرياض، عربستان سعودى. 
Social Reading of Saudi women situations in Banat Al-Ryadh of Rajaa

Al - Saane

Dr.Ali Afzali

Assistant Professor, Department of Arabic Literature, University of

Tehran

E-Mail: ali.afzali@ut.ac.ir

Dr.Raheem Attaby

Assistant Professor, Department of Persian Literature, University of

Baghdad

E-Mail: drraheem2004@ colang.uobaghdad.edu.iq

Masoumeh Mohseni Mehr (Sagvand)

M.A of Arabic Literature, Islamic Azad University- Dezfoul Branch

Abstract:

The identification of social, cultural themes, on base of social point of view can show us the real pictures of the time the writer of the novel live in. In this paper, we try to consider the various layers in Banat Ryadh (Riadh's Daughters), the novel of Rajaa AlSaane. The famous writer of Kingdom of Saudi Arabia, in Banat Ryadh, with realistic view, was manifested the abnormal situation of his generation in KSA.The writer's multilateral acquaintance of district and area, the creation of strong language and descriptions, the lovely and touchable personalities, the direct and attractiveness narration, the real and belivable representation of cultural,opinions and troubles of the people, the honesly pictures of traditionalism, are the important social factors in this novel. Raja AlSaane in this novel, with symbolic language, criticized the social and cultural condition of the women in KSA.She has described the women spiritual crisis and their interior paradoxes and contradictions.

Key Words: Modern Arabic Novel, Social Criticism, Banat Al- Ryadh, Rajaa Al-Saane, KSA.

\section{القراءة الاجتماعية لظروف المرأةة السعودية فب (واية بنات الرياض : (جاء الصانع}

\footnotetext{
الملخص:

علم الاجتماع الأدبي هو واحد من الأساليب الجديدة نسبيا في الدراسات الأدبية. ومن أكثر أهمية في هذا النقد هو آلئ

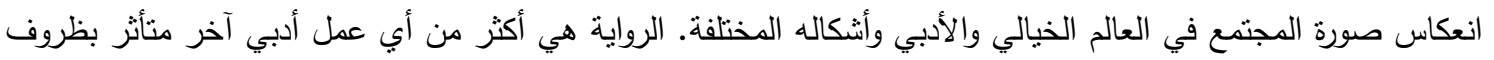

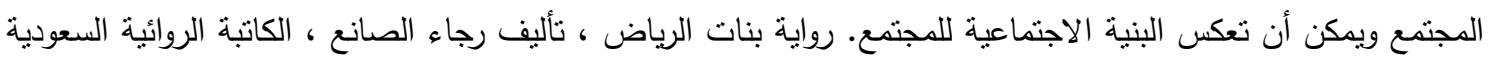
المعاصرة ، هو عمل واقعي يتضمن أحداثه ومؤشراته الموضوعية على حياة الكاتبة وفيما يتعلق بقضايا المرأة السعودية ،

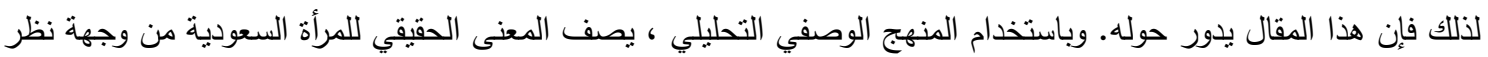

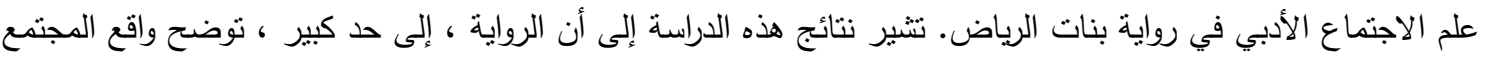

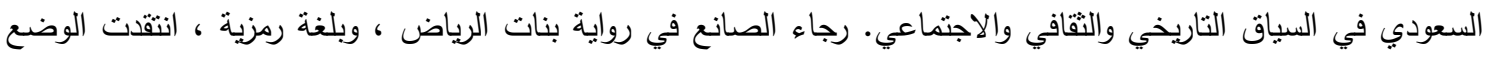

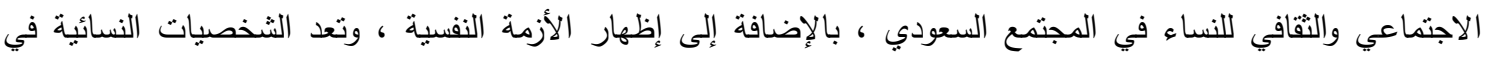
القصة رمز لمشاكل المجتمع السعودي وتصوير مآسي النساء في البلاد وصراعاتهن الداخلية. ومع ذللك ، فإن جهود وتركيز الإني الكاتبة على استيقاظ الخطوط الحمراء للمجتمع السعودي دفعته إلى اتخاذ نظرة متحيزة وأحيانًا غبر عقلانية. الكلمات المفتاحية: رواية عربية معاصرة ، قراءة اجتماعية ، رجاء الصانع ، بنات الرياض ، المملكة العربية السعودية.
} 


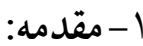

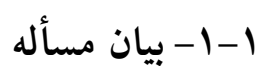

نقد ادبى از آغاز تا سالهاى نه جِندان دور به بررسى صور خيال و ابزارهاى بيانى يكى اثر هنرى متمركز بود

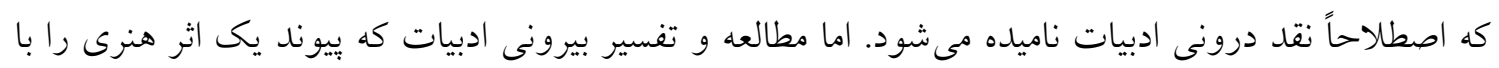
جريانات اجتماعى، سياسى و فرهنكى معاصر آن مورد بررسى قرار مىدهد به كمك دانشهايى تجون

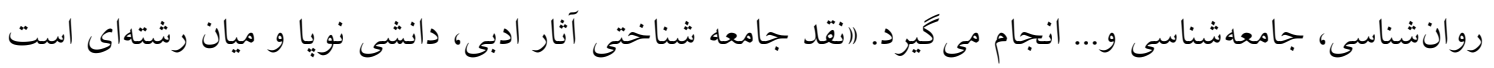
كه به بررسى طبقات مختلف جامعه و طرز رفتارها و كنشهاى متفاوت و متشابه ساختارهاى اجتماعى در

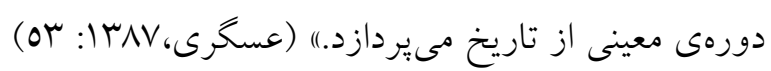

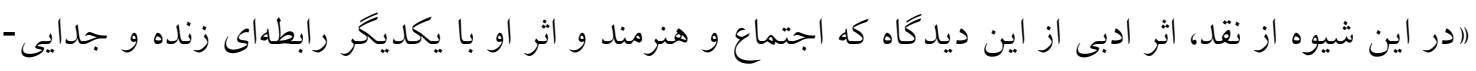

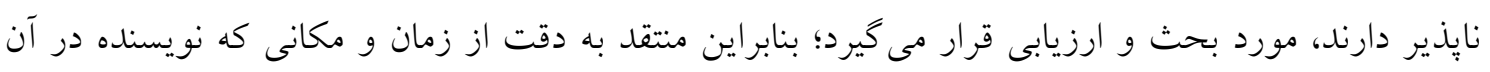

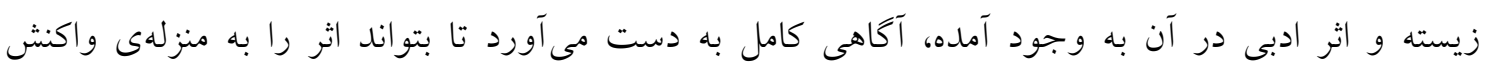

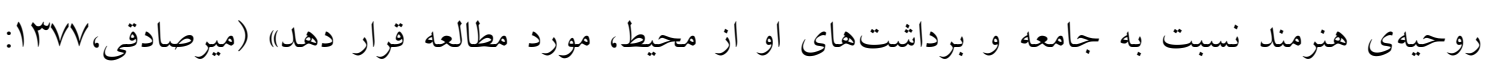

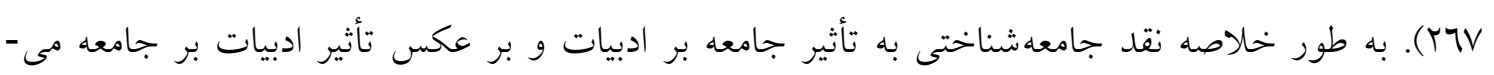
קיردازد.

يكى از مسائلى كه در خوانش يك اثر ادبى مورد توجه قرار مى گيرد، بررسى نحوه بازخورد تصوير اجتماع و

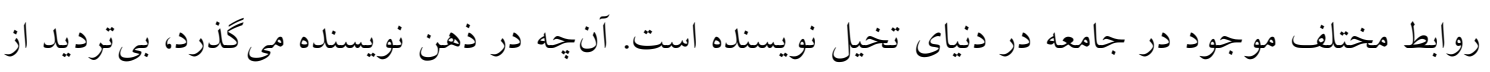

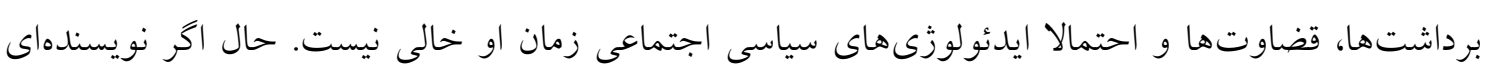

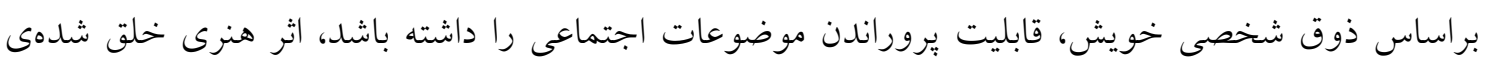

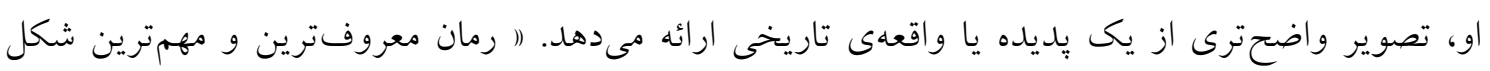

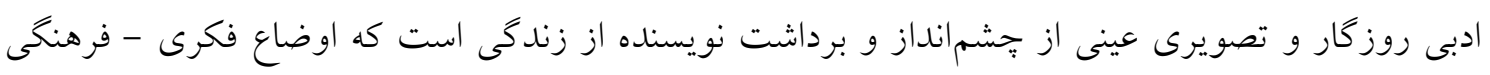

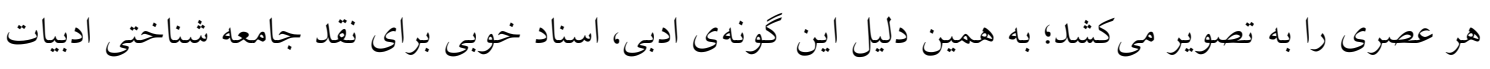

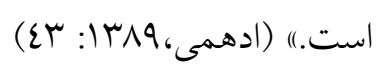

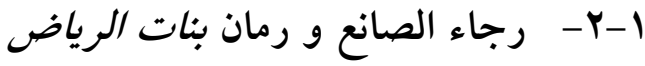

رجاء عبداله الصانع نويسنده و رماننويس عربستانى در لا سيتامبر سال ال191ام. در شهر رياض ديده به

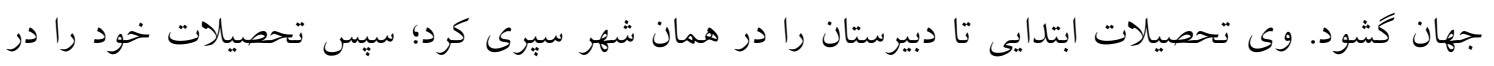

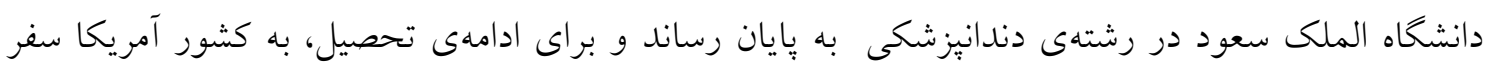

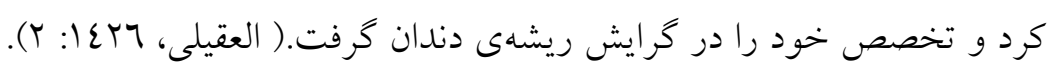
حوادث رمان بنات الرياض در شهر رياض، يايتخت عربستان سعودى اتفاق مىافتد و قهرمانان اصلى اين

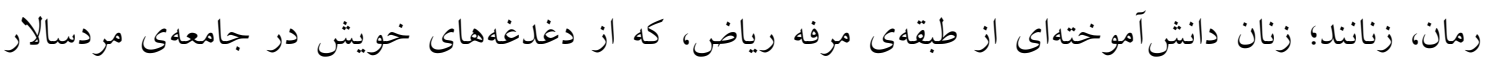

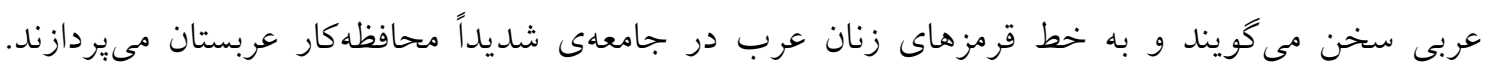


داستان از زاويه ديد داناى كل، روايت مىشود و با به تصوير كشيدن زندگى و احساسات عاطفى جهار دختر جوان متعلق به قشر مدرن جامعلى عربستان كه قراردادهاى عرفى و سختخيرانهى جامعه عربستان را بـه جإلش مى گيرند، آغاز مى گردد. در اين داستان دخترى به اسم " مُوا ) طى يكسال و در جمعلهى هر هفته، ايميلى به تمامى كاربران ايتترنت در

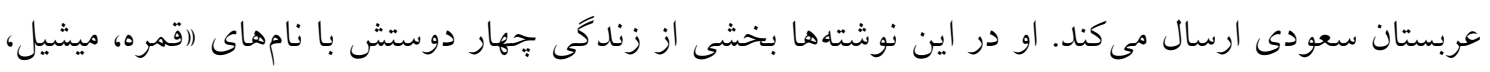
سديم و لميس" را به تصوير مى كشد: قمره فارغ التحصيل رشته ادبيات از دانشگاه عربستان است كه با راشد ازدواج مى كند و به آمريكا مهاجرت مى كنند. در آنجا متوجه سردى همسرش نسبت به او و وجود نفر سومى در زندكىشان مى شود. در انتها با

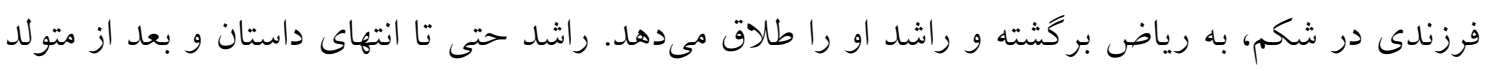

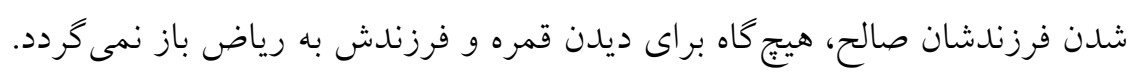

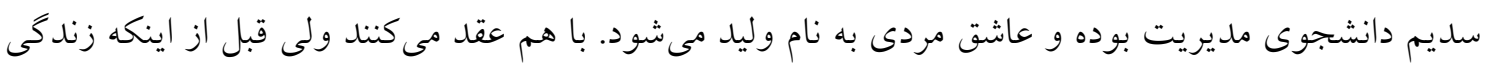

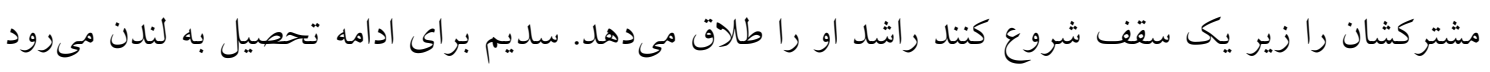

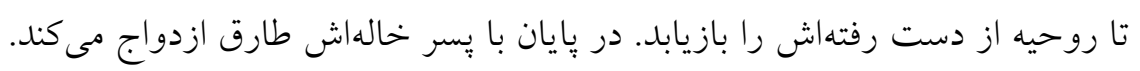

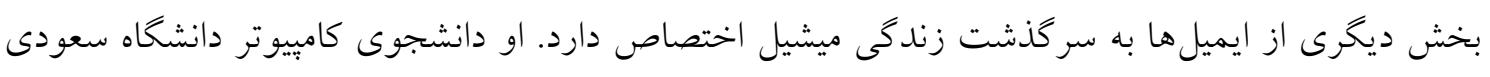
است. با يسرى به نام فيصل آشنا مى گردد، به او دل مىبندد و با وى قول و قرار ازدواج مى گذارد، اما يِ از كذشت يك سال، به دليل مخالفت خانوادهى فيصل، اين ازدواج سر نمى گيرد. پِ از اين شكست عاطفى، ميشيل با موافقت خانواده، براى ادامهى تحصيل راهى سانفرانسيسكو مىشود و مدت جهارسال در آنجا اقامت مى كند. وى در اين مدت به يسر دايىاش متى علاقهمند مى گردد و پِ از اتمام تحصيلاتش به رياض باز گشته و خانو اده را از علاقهاش مطلع مى گرداند اما خانو اده با وى به شدت مخالفت مى كنند؛ جرا كه يسر دايىاش، مسيحى است؛ درحالى كه ميشيل مسلمان است. ميشيل پس از اين شكست عاطفى دوم، به همراه خانواده براى زندگى، راهى دبى مى گردد و در آنجا در تلويزيون مشغول كار مىشود.

شخصيت پايانى كه در ايميل ها به آن يرداخته شده، شخصى با نام لميس است. لميس نسبت به سه دوست

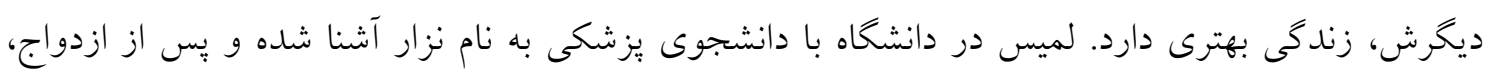
زندكى بسيار موفقيتآميزى را تجربه مى كنند.

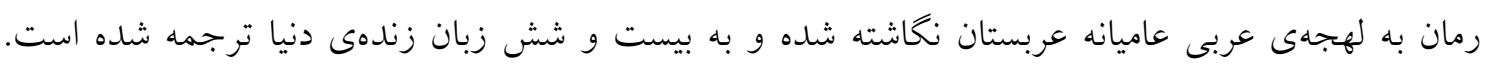

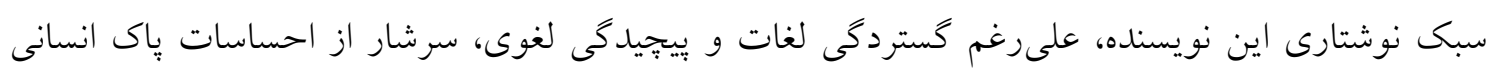




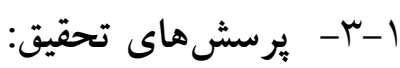

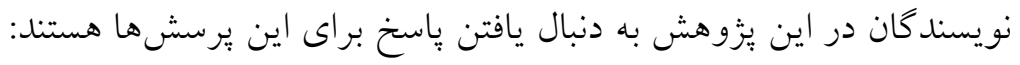

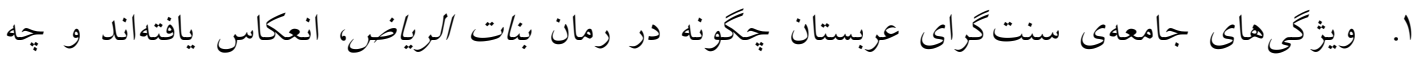

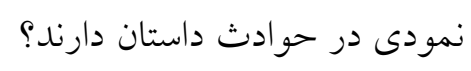

r. عقايد نويسنده و تجربيات او از زندكى در عربستان، به جهه صورت در رمان بنات الرياض تجلى

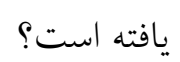

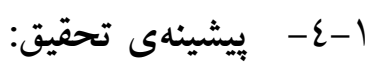

مطالعهى جامعهشناختى رمان عربى در ايران از يزووهشهاى مورد علاقهى محققان بوده است. از جملهى اين

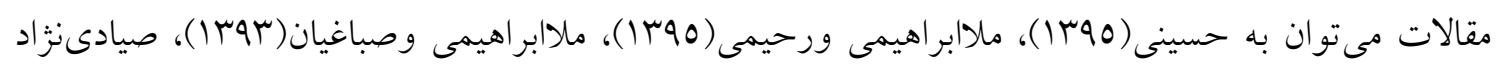

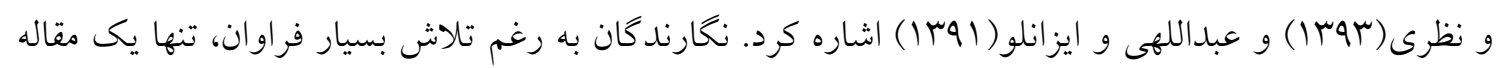

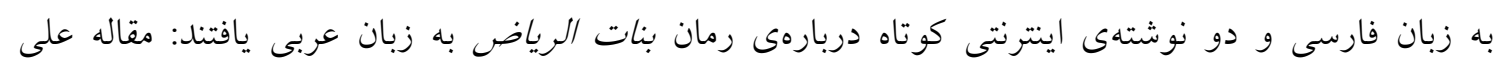

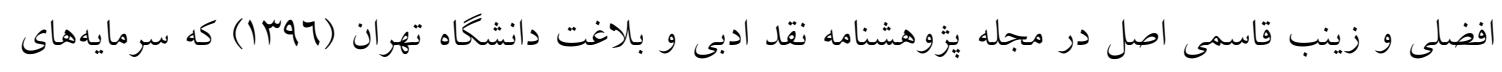

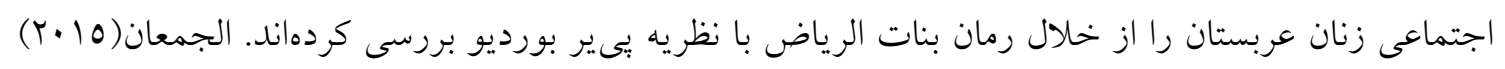

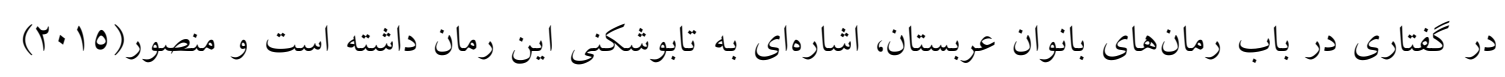

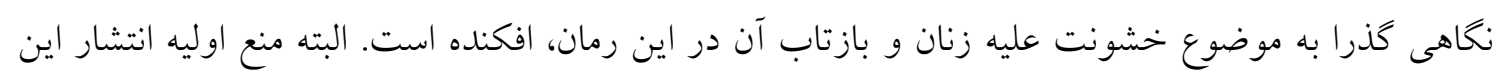

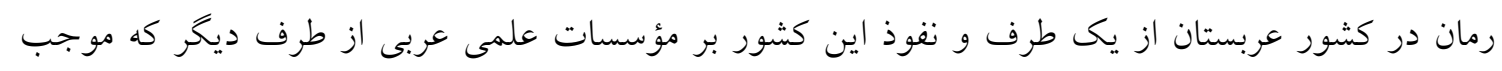

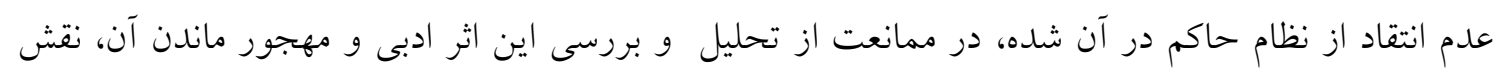
عمدهاى داشته است.

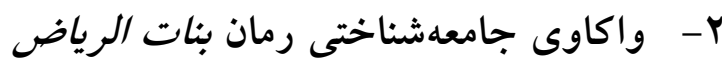

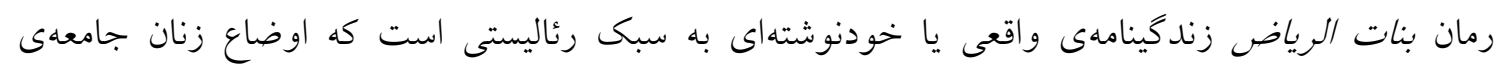

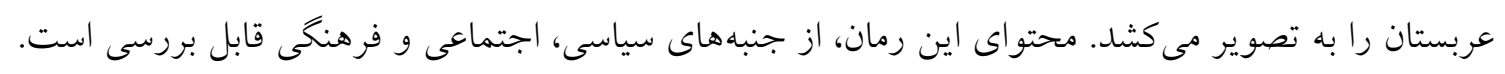

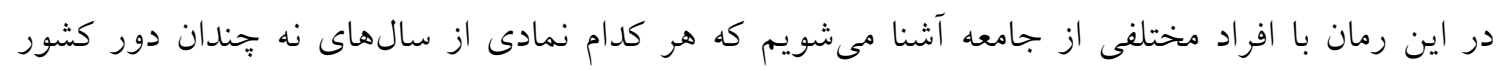

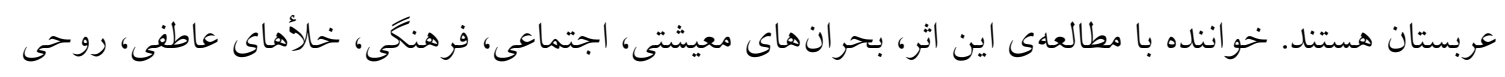

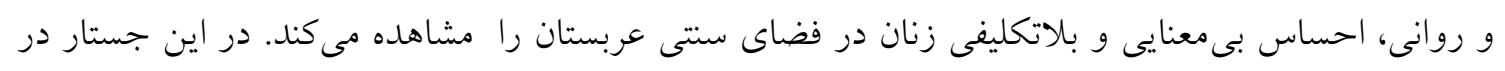

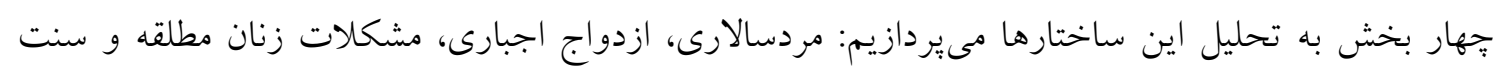
شكنى زنان.

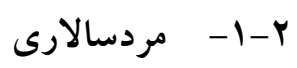

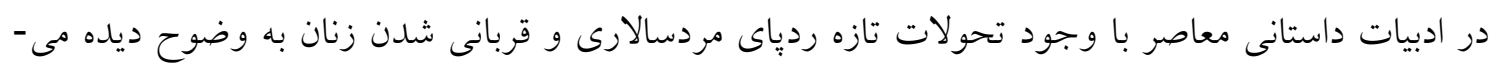

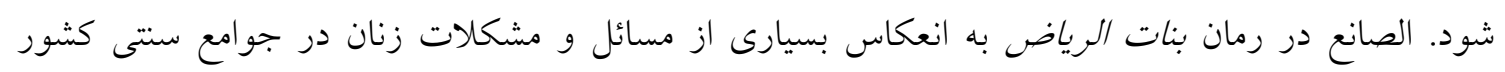


عربستان يرداخته و بدبختى و مصائب آنان را به تصوير كشيده است. وى در اين رمان به مسائلى از جمله: خشونت، تعدد زوجها، ازدواجهاى نامناسب اشاره كرده است. تحقيقات به خوبى كوياى آن است كه در قرن بيستم و بيستويكم در حالى كه زنان غربى، از بسيارى از حقوق برخوردار بودند، در جهان عرب، همجينان

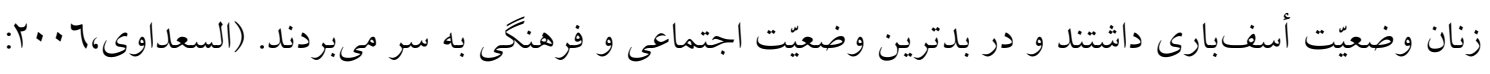
(T9) رجاء الصانع در خلال رمان بنات الرياض به زيبايى از اين وضعيّت اسفبار زنان عربستانى برده برمى -

در رمان بنات الرياض، راشد، شخصيّتى به تصوير كشيده شده كه تمامى حق و حقوق همسرش را يايمال

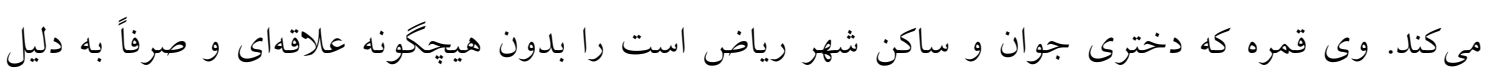
اصرار خانواده، تصاحب كرده و هستى وى را نيست و نابود و او را از طبيعى ترين حقوق يكى انسان محروم

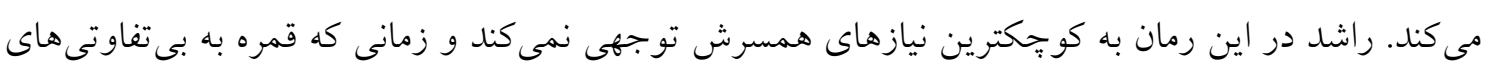

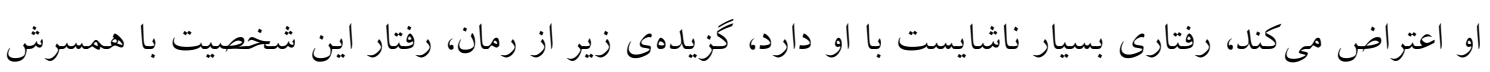

$$
\text { را به خوبى به تصوير مى كشد: }
$$

" جشمهايشان در يك لحظهى وحشتناك به هم گره خورد، جشمان قمره ير از ترس و و وحشت بود و

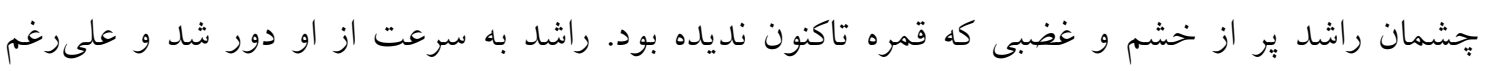

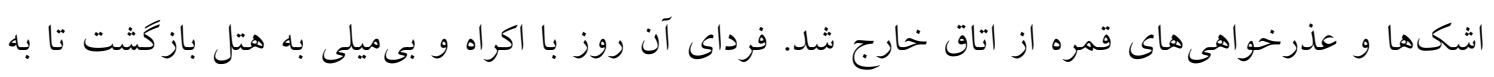

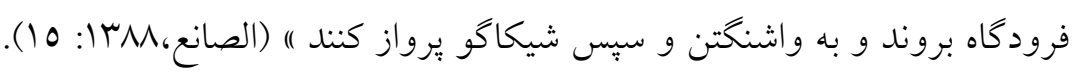
در اين رمان، قمره، اسير سلطه و سختخيرىهاى بى مورد همسر است، اختلافات شديد وى با همسر و عدم

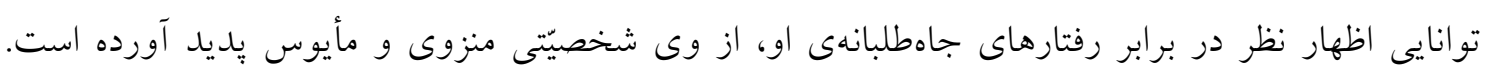

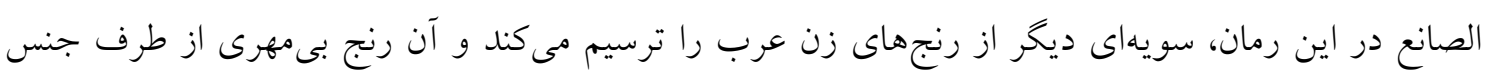

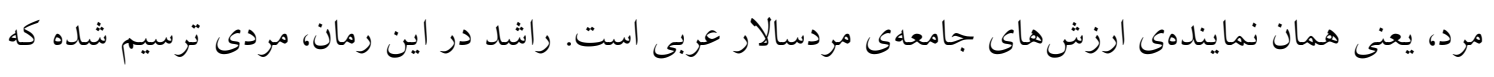

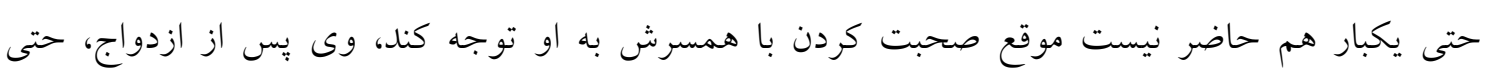

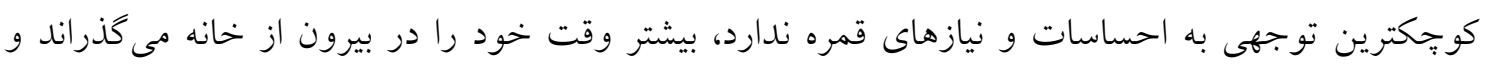
دائما از همسرش فرار مى كند:

" راشد از زمان رسيدنشان به شيكاكو، مشغول دانشگاه و بحث و درس شد. ساعت هفت صبح از خانه خارج

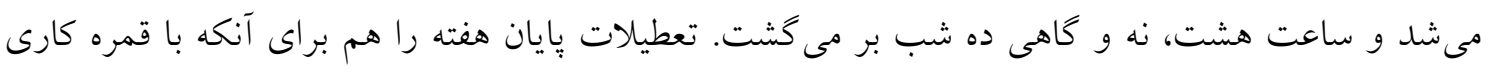

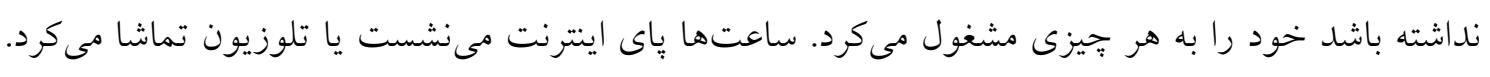

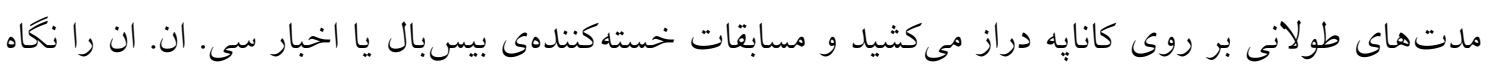

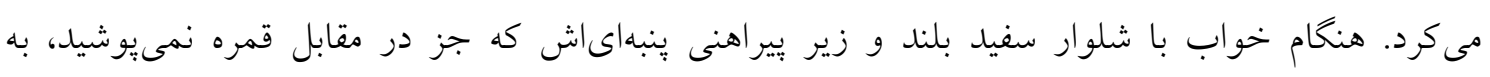

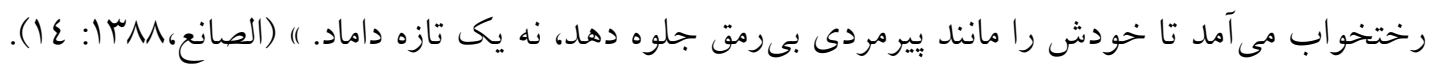

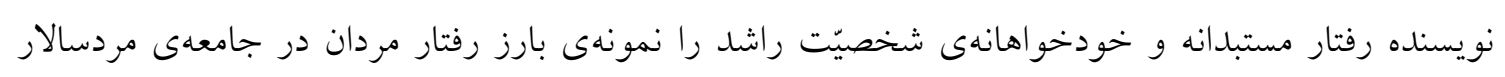

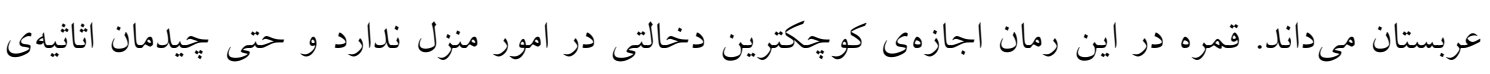


منزل مسكونىشان، تنها به سليقهى همسرش راشد است؛ اين رفتار خودخواهانهى راشد بيش از هر رفتار ديخرى به شدت قمره را عصبى و ناراحت مى كند: (إجيزى كه در مورد راشد بيشتر از هر تجيز ديخرى عصبانىاش مىكرد، تصميم گيرىهاى خودخواهانهى راشد

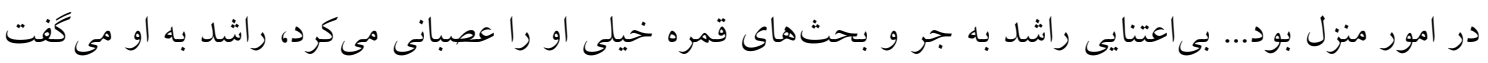

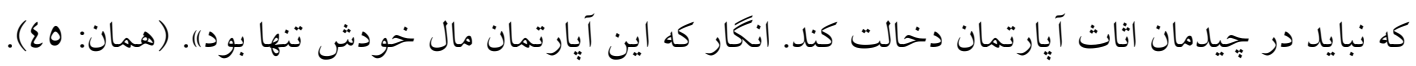
الصانع در جاى جاى رمان بنات الرياض به سلطه گرى و رفتارهاى ناشايست مردان در جامعهى مردسالار عربستان در برخورد با زنان اشاره مى كند. قمره در بخشى از رمان، سختى هاى زندگى زناشويى اش ران را به مادر

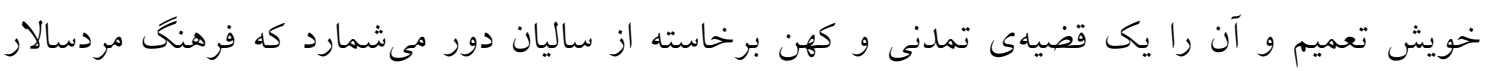

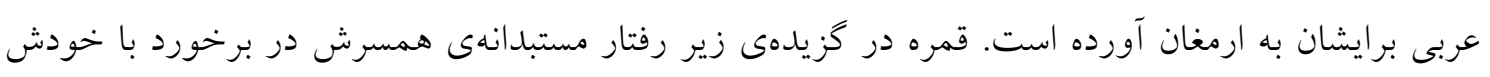
را همانند رفتار يدر با مادرش مىداند: (ا رفتار راشد با او، خيلى با رفتار يدرش با مادرش تفاوت نداشت).

(همان، (ه) (ه)

جرخش نسلها در اين رمان، وضعيّت زنان داستان الصانع را به خوبى نشان مىدهد، در ديدگاه الصانع

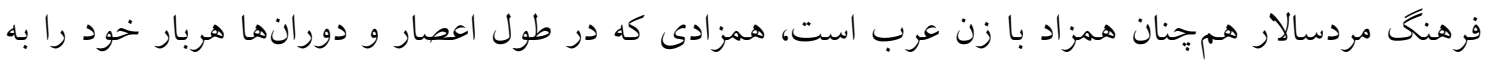

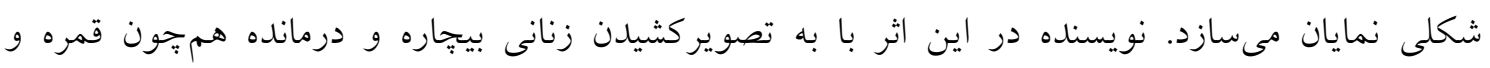

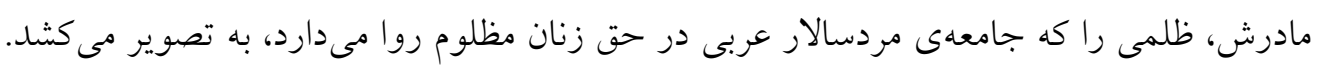

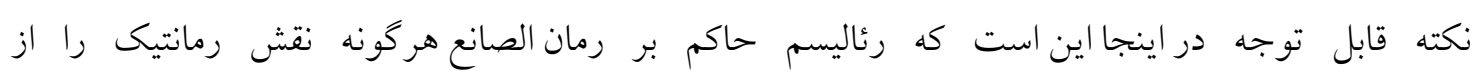

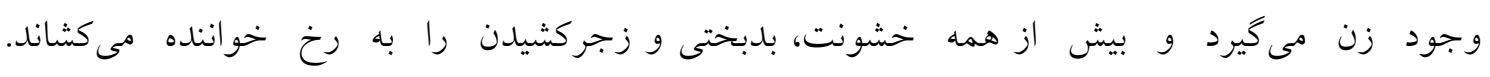

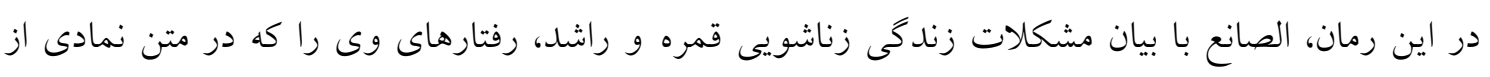
سلطه و هيبت اوست به تصوير مىكشد و اين جنين تسلط مرد و ضعف و وستميذيرى زن زن را ترسيم مى زئمايد.

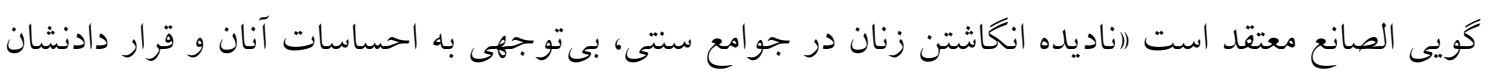

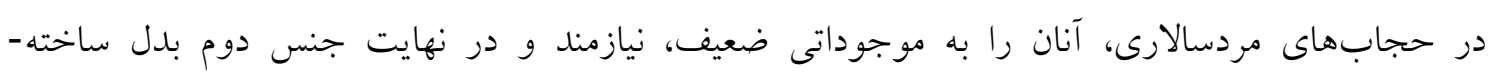

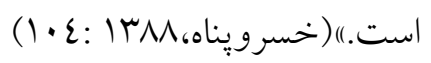
مادر قمره و زنان با تجربهى فاميل، تنها راه استمرار زندكى قمره در خنين شرايطى را در حامله شدن وى مى دانند: " زنان با تجربهى فاميل و همجنين مادر و نزديكانش به او كفته بودند كه حامله شدن راهى براى تضمين

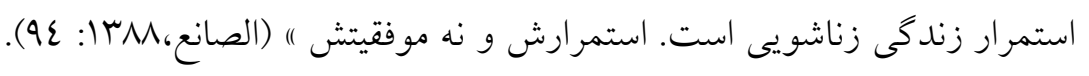

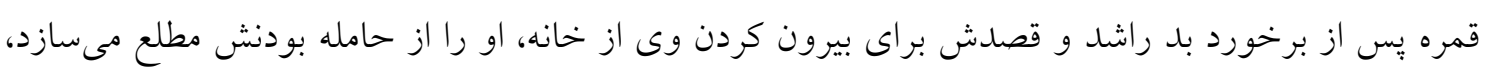

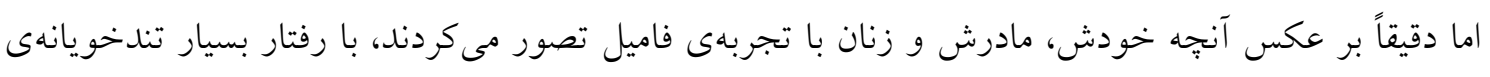

$$
\text { راشد مواجه مى شود: }
$$

(اسيلى دوم هم فرو آمد و در حالى كه با سوز و آه و ناله راشد را نفرين مىكرد، روى زمين افتاد، راشد از

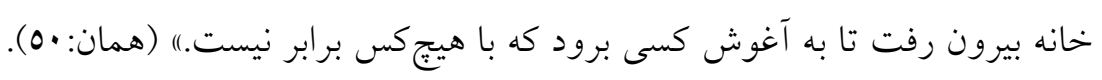


و اين جنين الصانع در گزيدهى فوق از مردسالارى حاكم بر جوامع سنتگراى عربى يرده برمىدارد؛

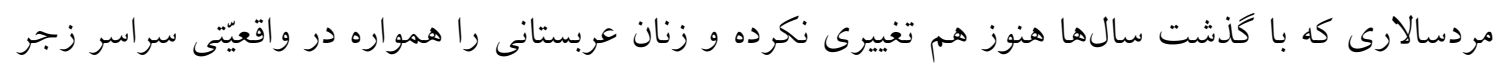
و نقص قرار داده است؛ كويى "وضعيت زن عرب به مانند زخمى است كه هيجز كاه التيام نمىيابد.) (وادى، (Y) (YVIV) در رمان بنات الرياض بر خلاف انتظار قمره، يّ از كذشت دو هفته از بازگشت وى به خانهى بدرىاش

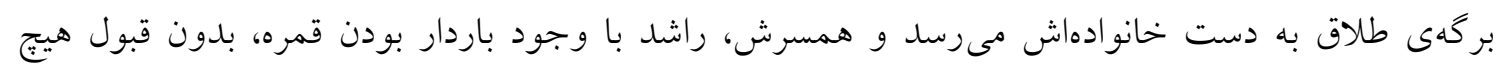
مسئوليتى، خود را براى هميشه از شر او و فرندش مىرهاند:

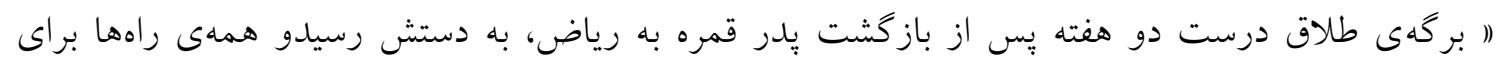

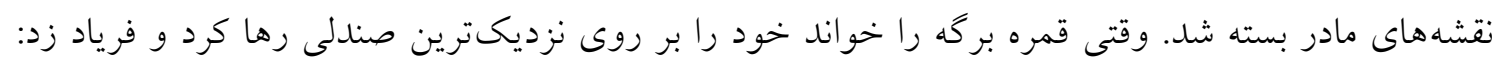

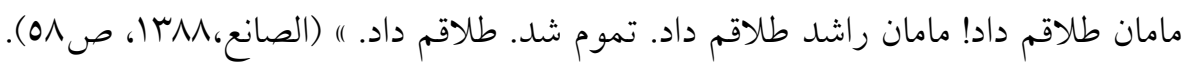
رجاء الصانع در اين رمان با نماياندن رويدادهاى ترازيكى از اين دست، قوانين جامعلى مردسالار عربستان را راد

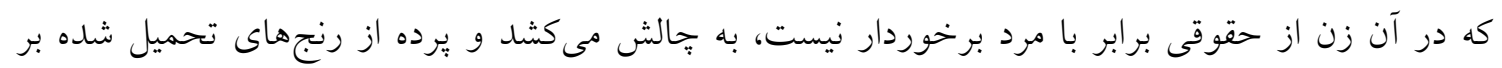
زنان مظلوم كشورش برمىدارد؛ زنانى كه به اجبار در مقابل سنتهاى نادرست رايج در جامعهى مردسالار

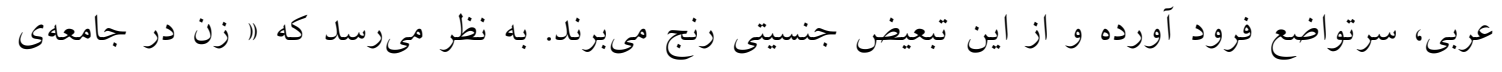

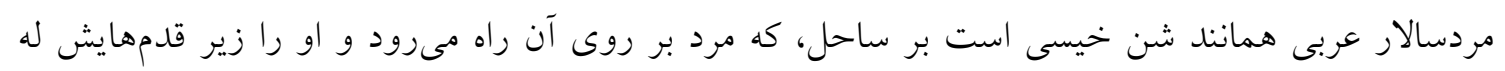

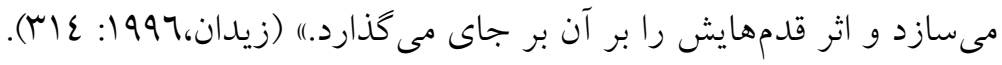
يكى از نقدهاى بسيار عالى نويسنده، متوجه فضاى مذهبى حاكم بر جامعه عربستان است اما نَه به اين معنا كه كانه

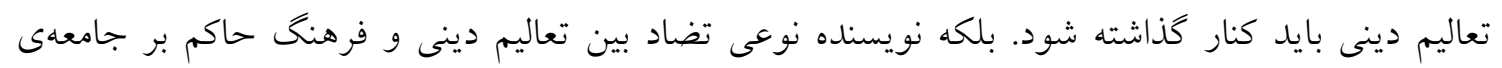

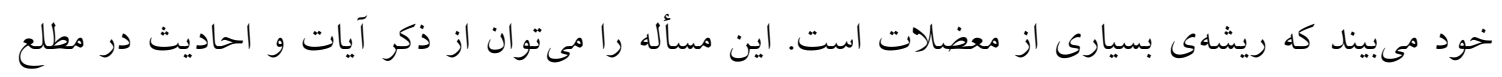
بسيارى از بابهاى رمان دريافت. مثلا در اول باب ك ا، حديثى را نقل مىكند كه ييامبر (ص) همواره در

خدمت اهل منزل بود. الصانع با ذكر اين ارزش دينى، به دنبال انتقاد از رفتار راشد نسبت به به قمره است است.

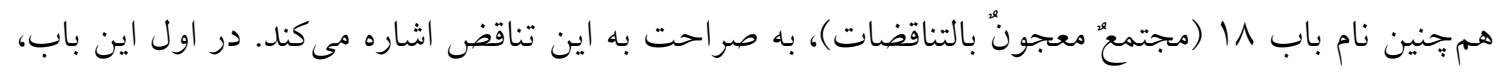

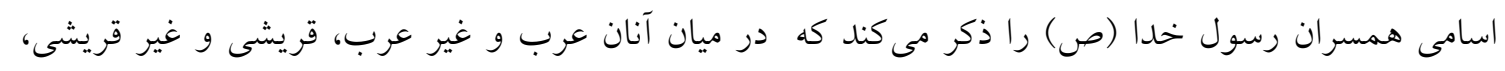

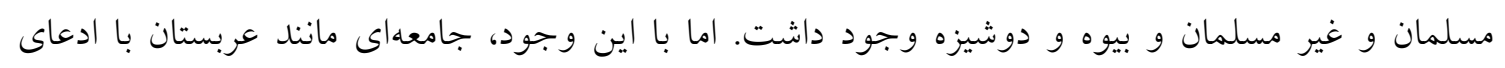
دين دارى، بيامبر و الكوى خود را فراموش مى كند.

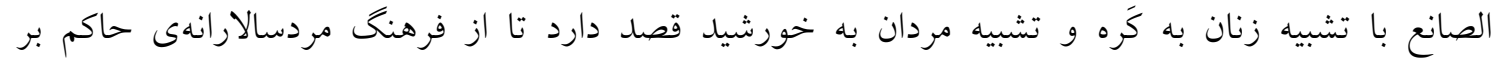
كشورش آشكارا سخن بكويد:( مادر قمره، زن را مانند كره و مرد را مانند خورشيد مىدانست.) (همان: V).

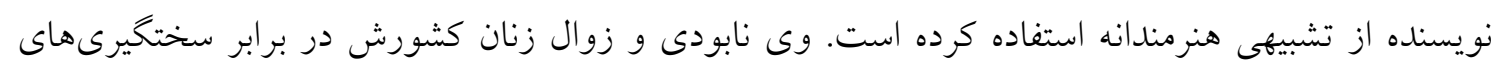
جامعهى مردسالار عربستان را به آب شدن كره در مقابل خورشيد تشبيه كرده است. 


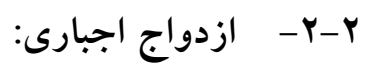

فرهنگ سنت كرا و مردسالار جامعلى عربستان زير فشار مجموعهاى از انتظارات يكسان، زن را به سلطانهى

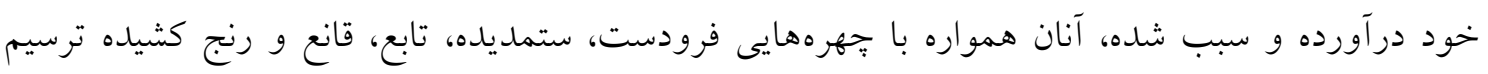

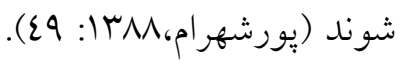

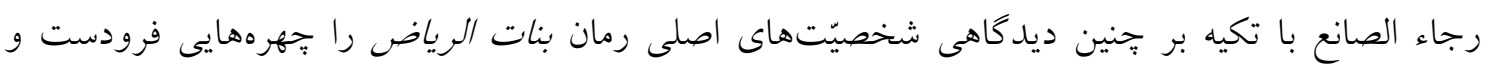

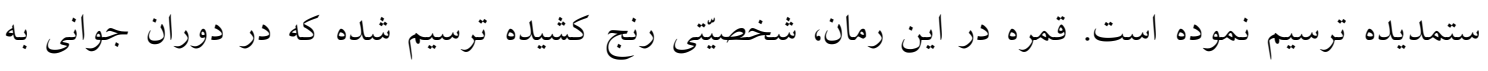

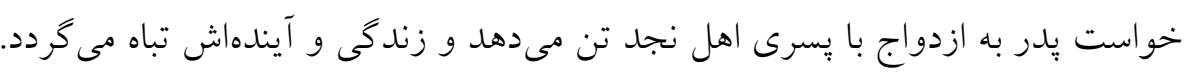

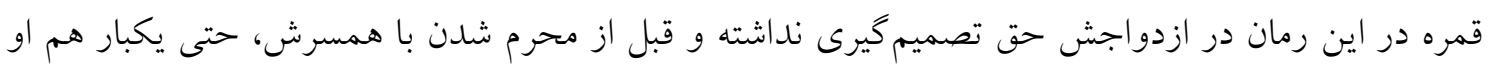

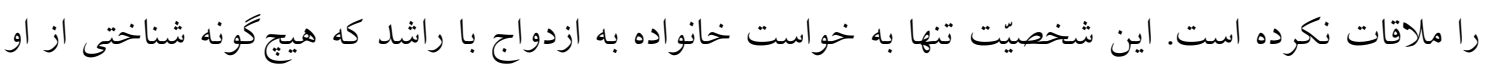

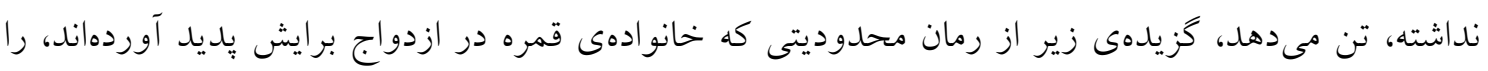
نمايان مى سازد: " ا قمره راشد را تا ييش از روزى كه به هم محرم شدند، نديده بود. با با اينكه آداب و رسوم خانوادهى قمره به

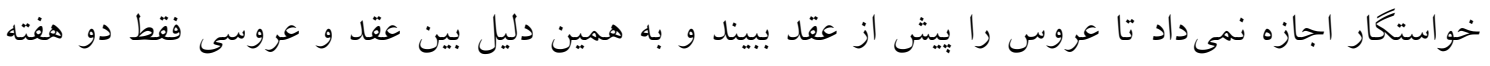

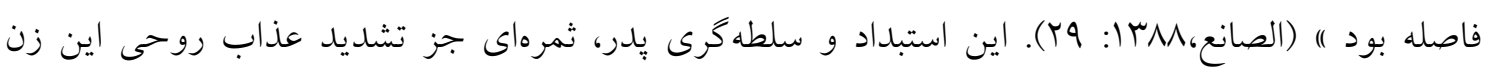

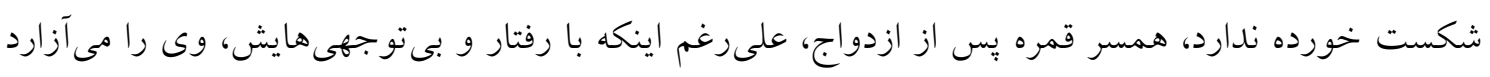

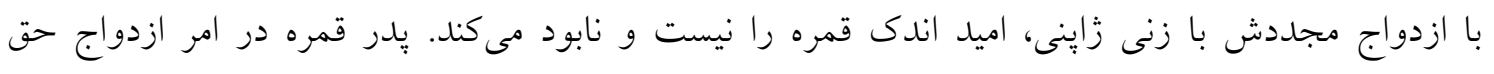

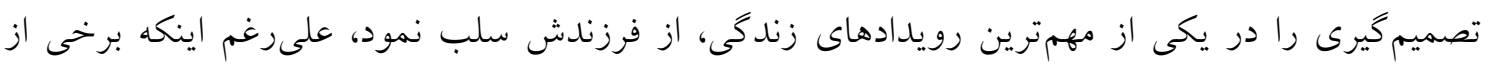

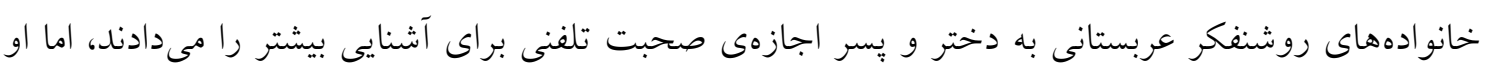

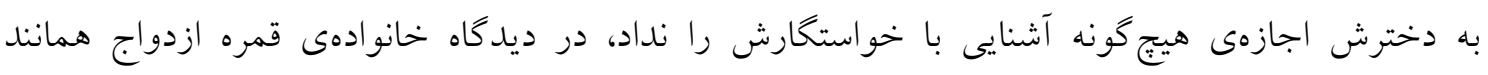

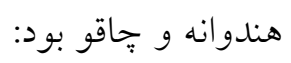
" قمره شنيده بود كه اغلب بسرها براى آشنايى بيشتر با نامزدهايشان بيش از مراسم عقد، تلفنى با هم در

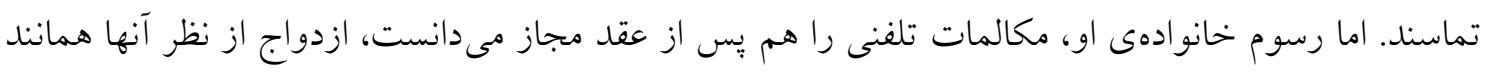

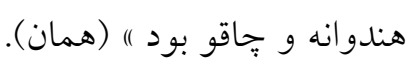

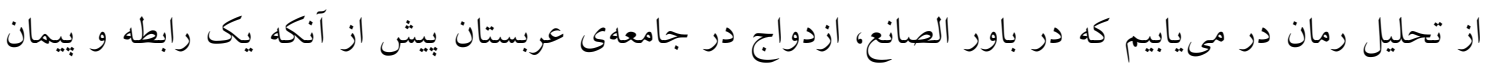

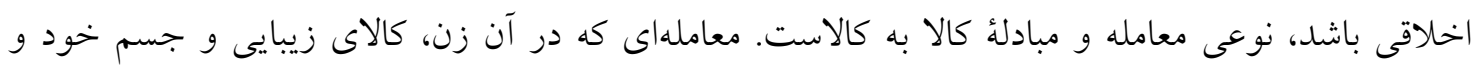

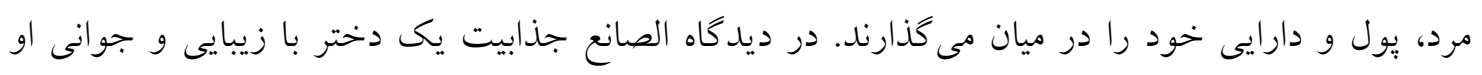

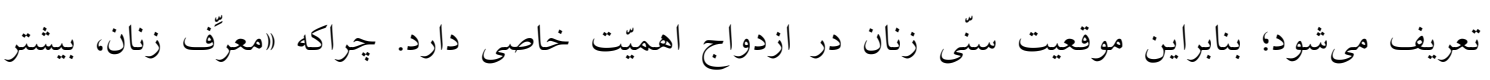

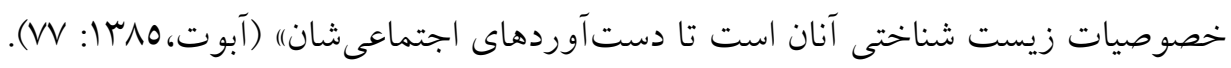

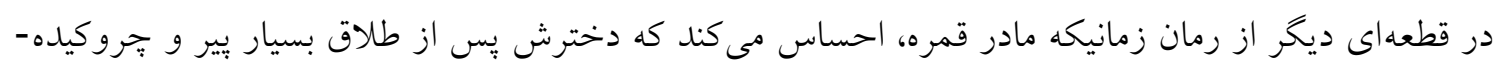

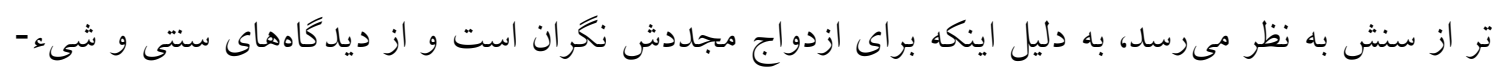


انخارانهى مردم كشورش اطلاع دارد، تصميم مى گيرد قمره را براى عمل زيبايى صورت به لبنان ببرد، تا شايد موقعيّت بهترى براى ازدواج مجددش بيش آيد:

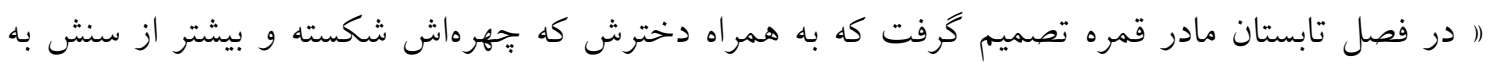
نظر مىرسيد و بقيهى خانواده يك ماه به لبنان سفر كنند. در لبنان قمره تسليم برنامههاى زيباسازى سمكره

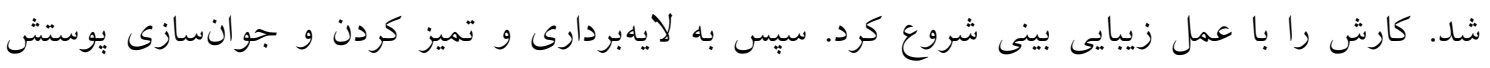
يرداخت و زير نظر متخصصان زيبايى اندام، رزيم غذايى سخت و تمرينات ورزشى را يى كرفت و در نهايت

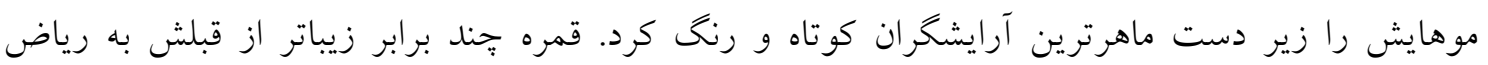

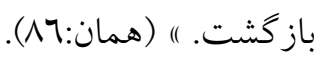

r-r r-r - مشكلات زنان مطلّقه:

رجاء الصانع عقيده دارد كه فرهنگ جامعهى مردسالار عربستان، زنان متأهل را محدود ساخته، جايگاهشان را تا پايين ترين حد ممكن تنزل داده و آنان را از حق و حقوق طبيعى خويش محروم ساخته است؛ به كونهاى كه كمتر زن متأهلى در جوامع مردسالار جرأت و جسارت انديشيدن به جدايى و مطلقه شدن ران را دارد. مادر

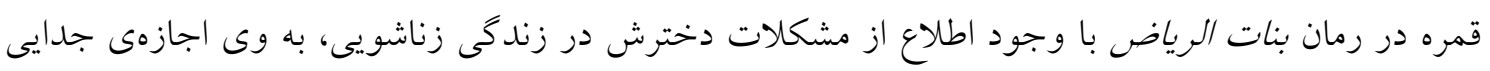

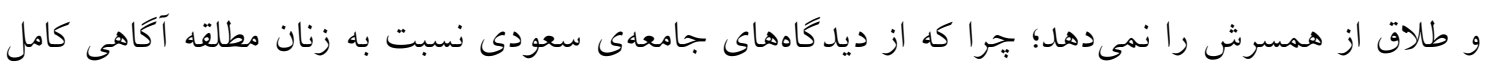

" مادرش كفته بود: اگه من مادرتم، طلاق بى طلاق. همين كه داداشت زنش و طلاق داد بسه، دخترامون

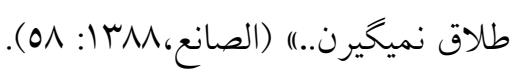

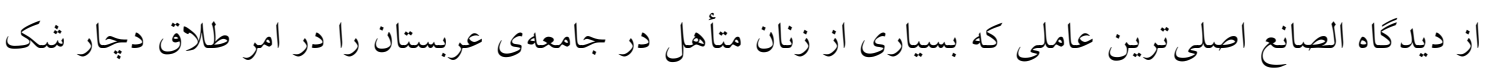

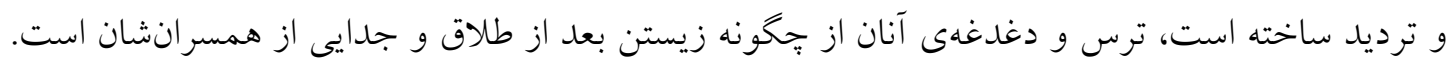

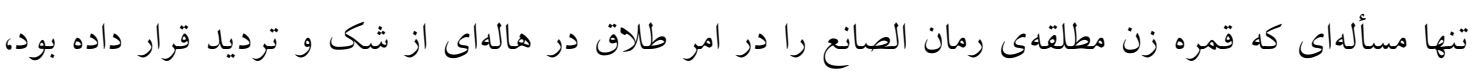
انديشيدن وى به جخكونه زيستن بعد از مطلقه شدن بود. كويى (ازنان مطلقه در ساختار قانونى و سنتى كشور

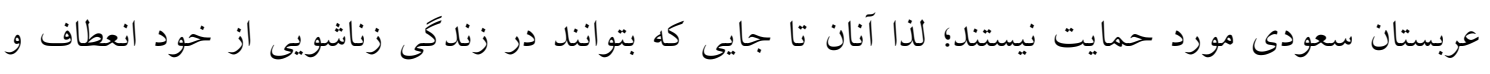

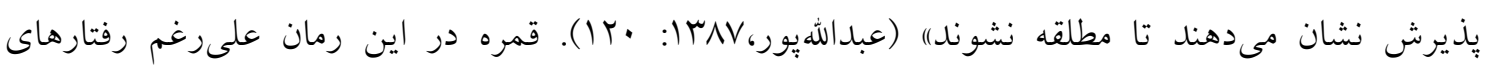
مستبدانهى همسر و حتى ازدواج مجددش، براى آنكه همسرش وى را طلاق ندهد، باردار مى شود و در برابر

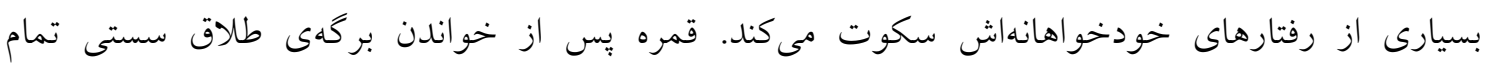

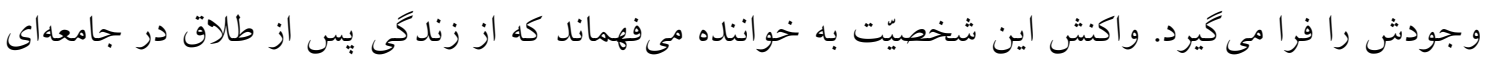

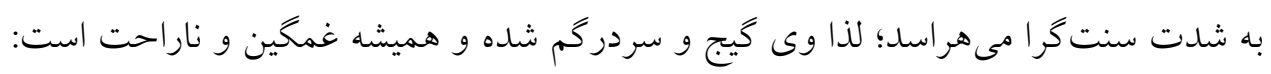

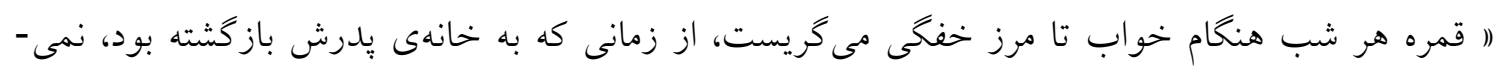

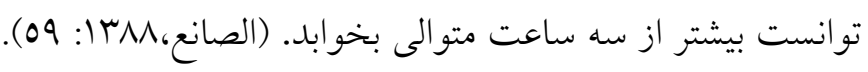


شخصيّت مطلقهى رمان، زنى حساس و شكننده ترسيم شده است، اين زن زخمهايى بر روح دارد و خود را در صحنهى زندكى و اجتماع نا اميد مى بيند، ترس، تنهايى و شكنندگى بر او غلبه كرده است. او دائما در

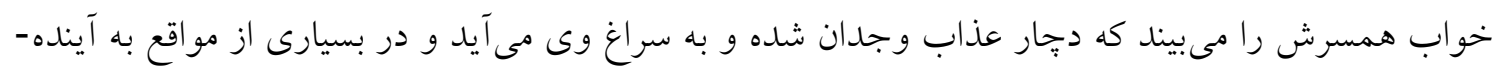
ى يوج و تباه شدهاش مى انديشد:

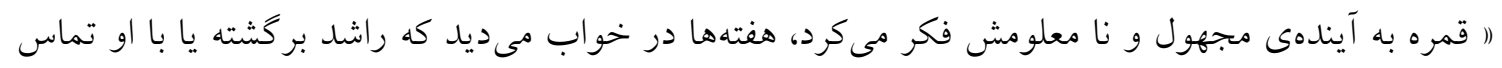

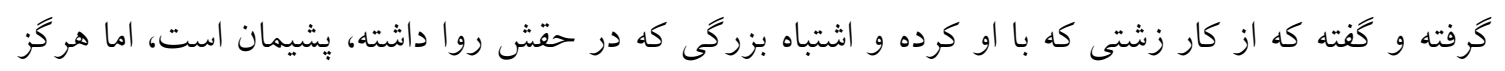

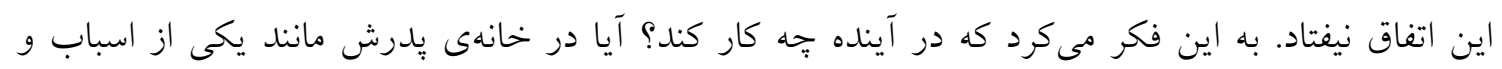

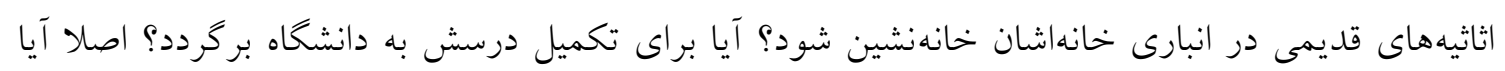

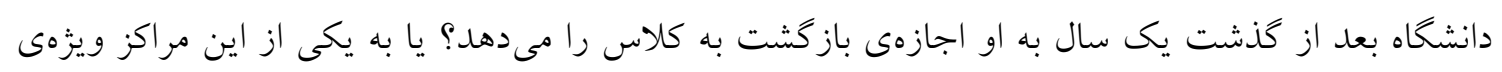
بانوان يا مؤسسات برود تا وقتش را ير كند و در آخر هم مدركى دريافت كند؟ ) (همان: (V). توصيفها حاكى از اين است كه نويسنده از بعد روانشناختى به ساختار درونى رمان نظر دارد، الصانع

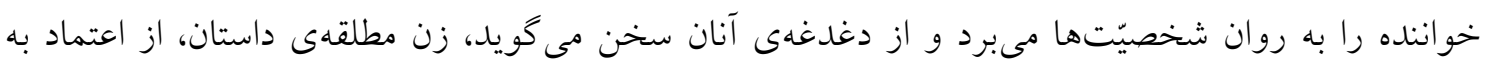

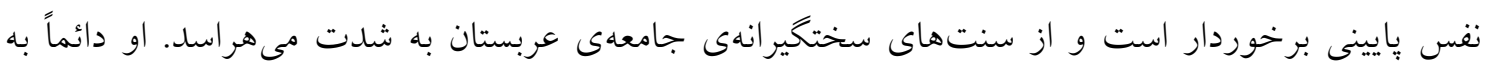
آيندهى نيست و نابود شدهاش مي بكرد.

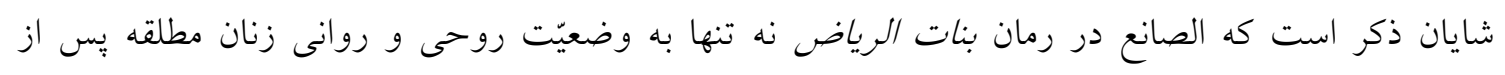

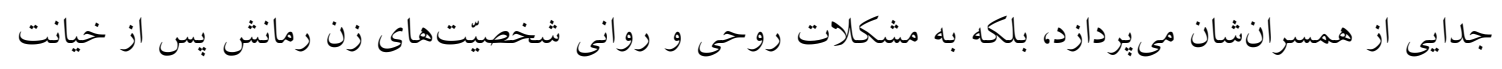

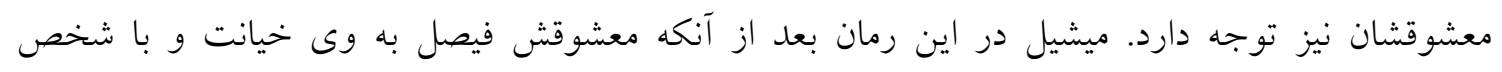

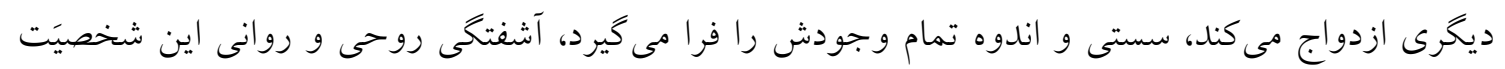

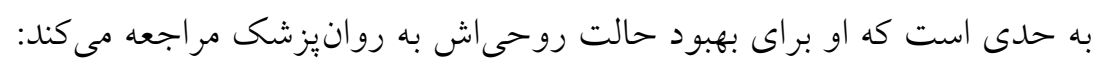

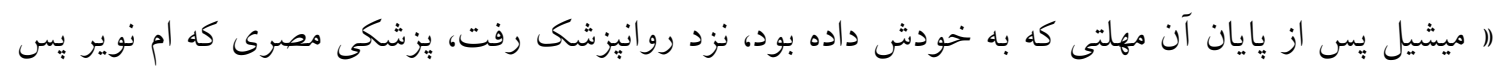

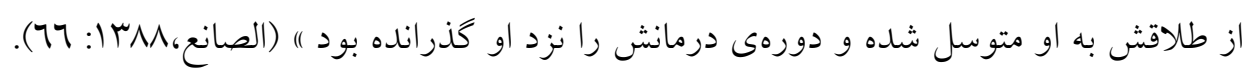
در واقع الصانع در اين اثر، زنانى ساده نقش مىزند كه به دنبال يكى زندكى عادى هستند. آرزوهايى ساده

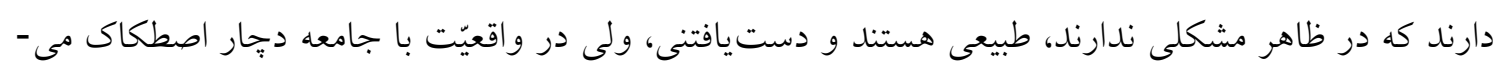

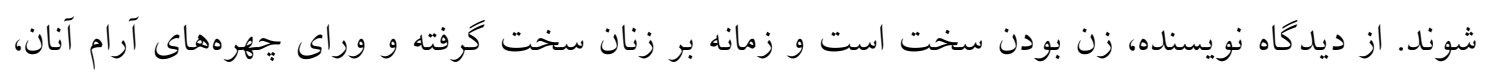

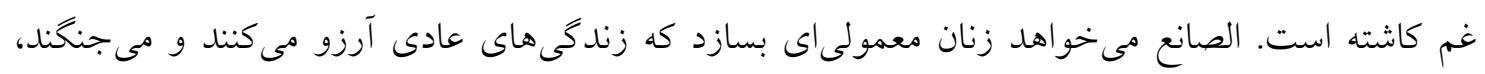

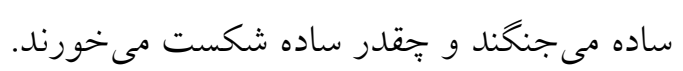

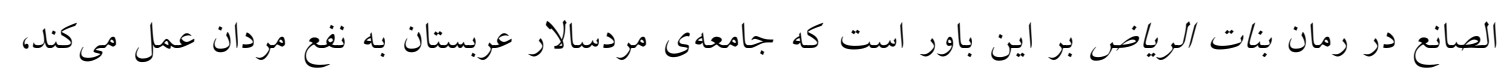

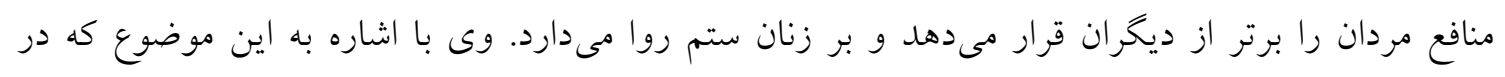

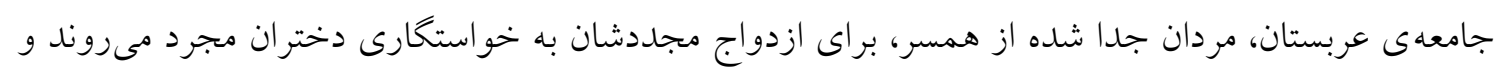

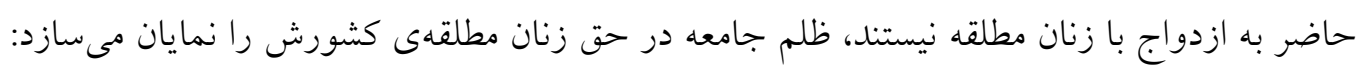
" مردهاى جدا شده هم مى گردن يه دخترى رو كه ازدواج نكرده باشه، بيدا مى كنن.) (همان:ب • (1) 
وى همجنين در قطعهى زير از رمان بر اين باور است كه در كشور عربستان مردان به هر دليلى و بدون در

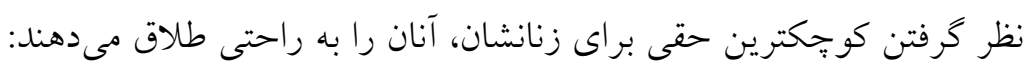

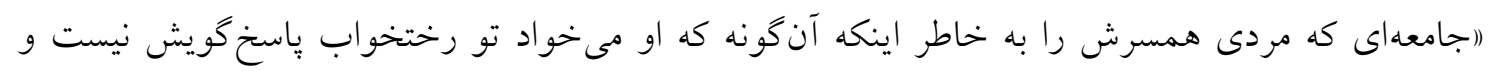

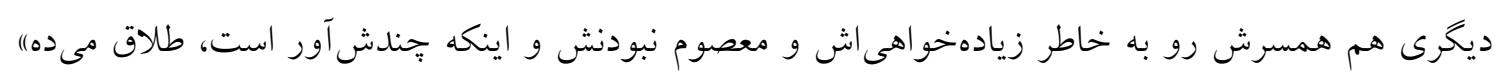

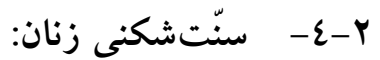

بىشى هر جامعهاى براى دستيابى به توسعهاى پيايدار، نيازمند مشاركت و حضور زنان در زمينههاى اجتماعى

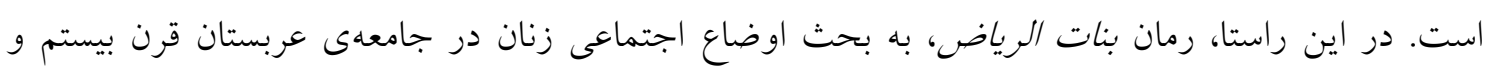

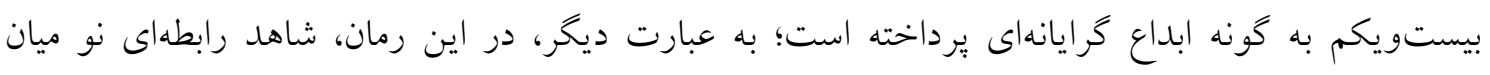

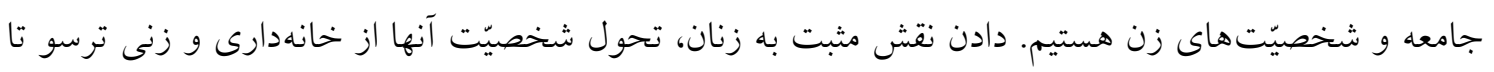

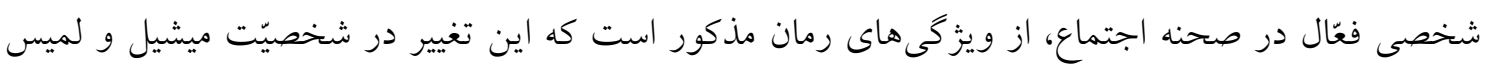
بيش از ساير شخصيّت ها قابل مشاهده است. رجاء الصانع در رمان بنات الرياض بسيارى از شخصيّت هاى اثرش را زانانى آزاد و سنتشكن ترسيم نموده

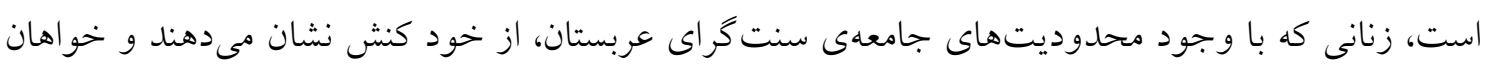
اتخاذ حقوق يايمال شدهى خويش در جوامع سنتى و مردسالارند؛ بارزترين سنتشكنى زنان إنى اين آثار:

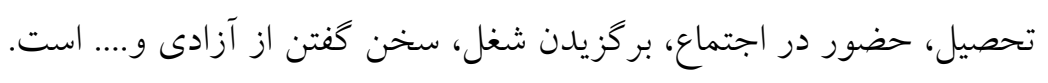

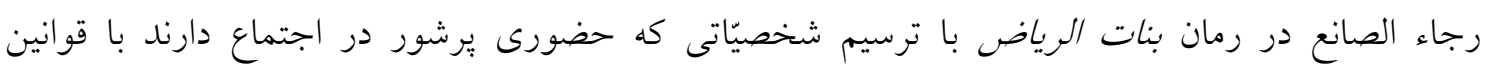

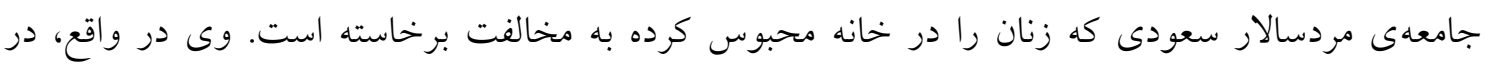
رمانش با ترسيم شخصيّاتى تحصيل كرده مانند: (ميشيل، لميس، سديم، قمره، ام نوير، تماضر و....) زنان را به

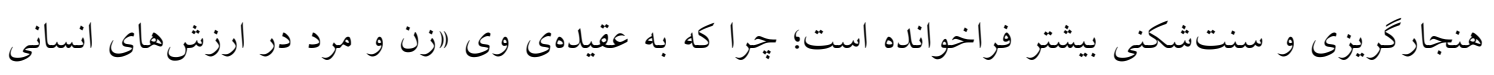

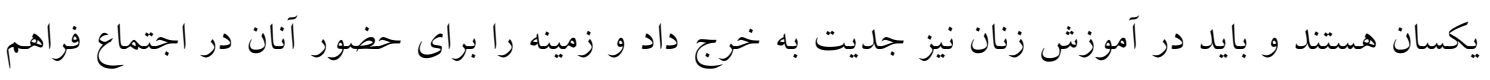

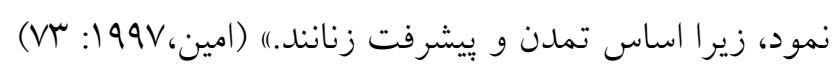

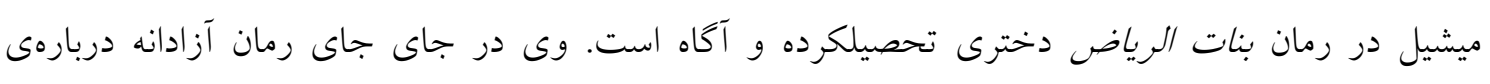
حقوق زنان كشورش سخن مى گويد. اين شخصيّت دخترى بى دباى و نترس است كه تمامى سنتهاى

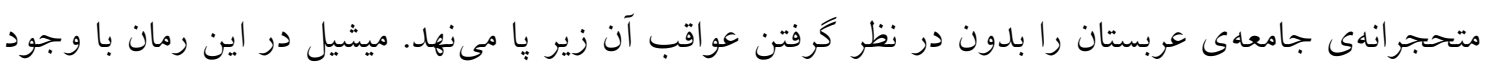

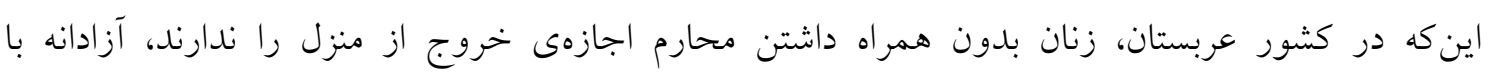

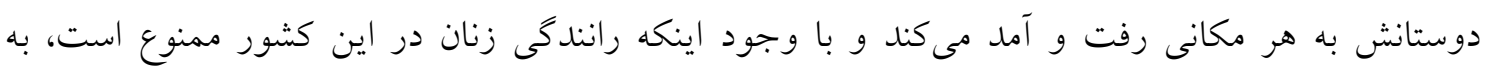
رانندكى در خيابانهاى شهر مى يردازد. كزيدهى زير از رمان، سنتشكنى اين شخصيّت را به تصوير مى كشد:

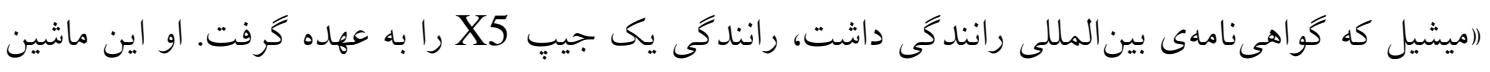
را كه شيشههاى كاملا دودى داشت از نمايشگاه اجارهى خودرو به نام رانندهى حبشى شانى ران كرايه كرده بود. 
لميس كنار ميشيل نشست و بنج دختر ديخر در صندلى عقب نشستند. صداى ضبط را زياد كردند و همراه با

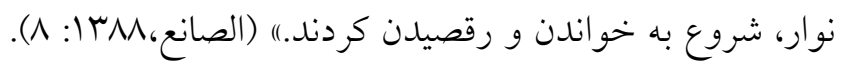

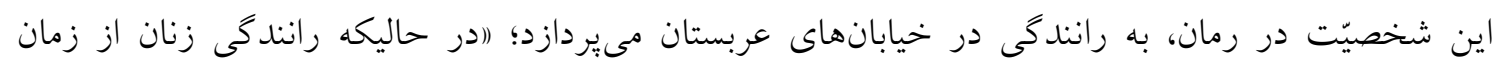

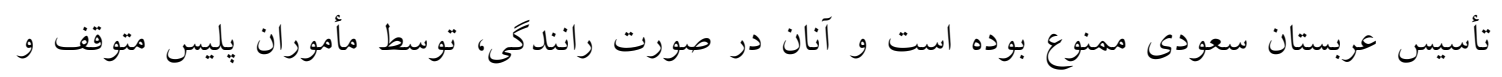
بازداشت مىشوند. عربستان سعودى تنها كشور در جهان است كه رانندگى زنان را ممنوع كرده است.)"

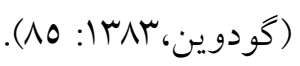
ميشيل در اين رمان، زن آزادى به تصوير كشيده شده كه حضورى برشور در ساير عرصههاى اجتماعى دارد و در تمامى رفتارش و حتى در يوشش از ديخر شخصيّت هاى زن رمان، متفاوت است، در جشن عروسى قمره

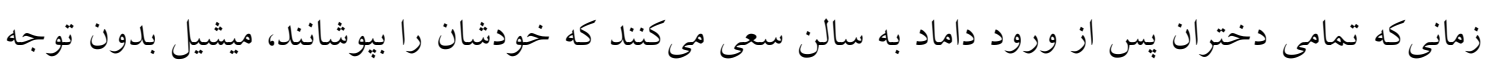
به نحاهها و قضاوتهاى زنان حاضر در مجلس به همان حالت قبل باقى ماند ماند و اين عمل وىى، تابوشكنى اين

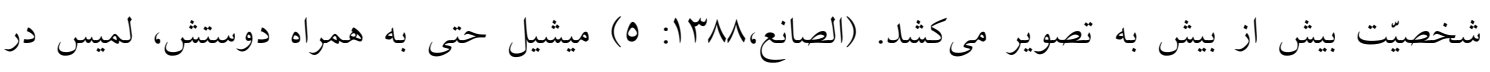

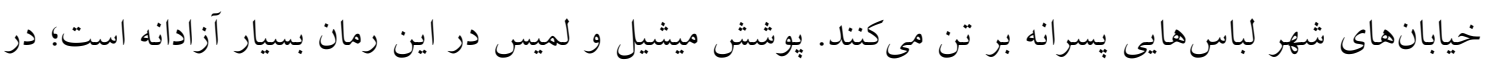

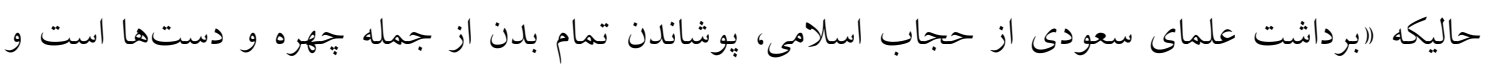
يليس دينى عربستان هميشه بر اين نوع يوشش زنان يافشارى مى كند. نيروهاى داوطلب در مركزهاى خريد،

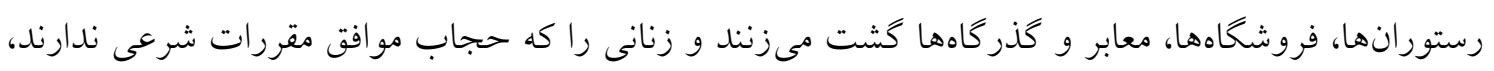

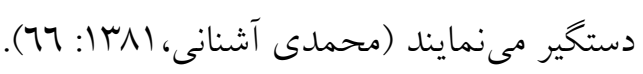
ميشيل در اين رمان زن بى يروايى است كه تن به هيجيك از سنتهاى جامعهى عربستان نمىدهد. وى وى با وجود اينكه در كشور عربستان اورود زنان بدون همراهى محرم به بسيارى از اماكن عمومى از جمله

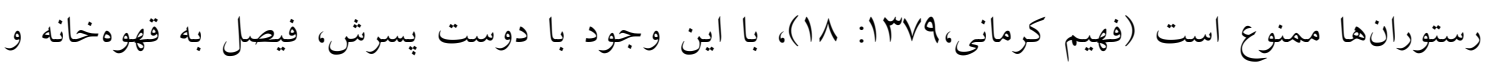

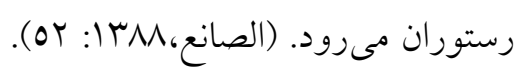

در اين رمان شخصيت ميشيل هرجند به واسطهى سنتشكنىهاى بيىدريىاش با فشارها و سختخيرىهاى

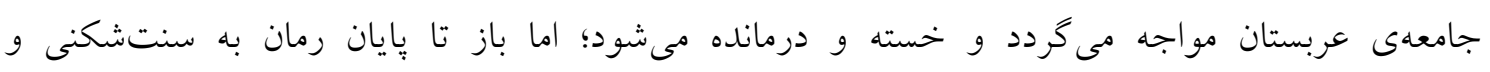
هنجار گريزىاش ادامه مى دهد.

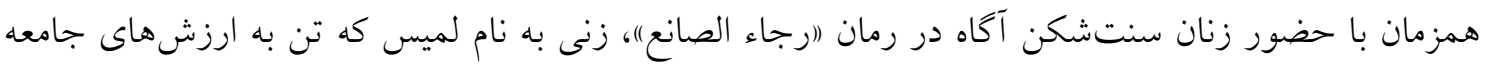

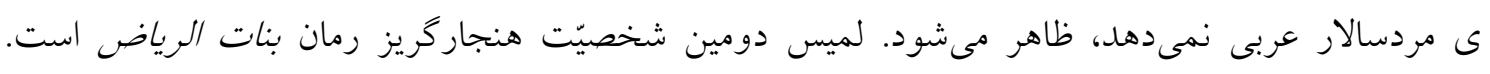

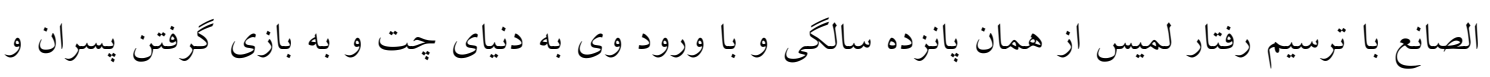

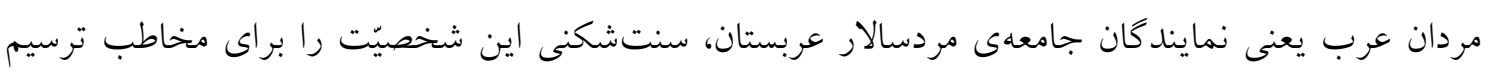
مى نمايد: (آشنايى لميس با اينترنت از وانزده سالكىاش آغاز شد. زمانى كه يدرش در بحرين، شروع به استفادهى از

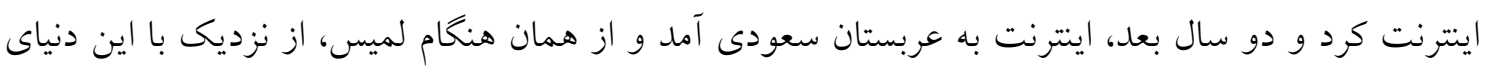

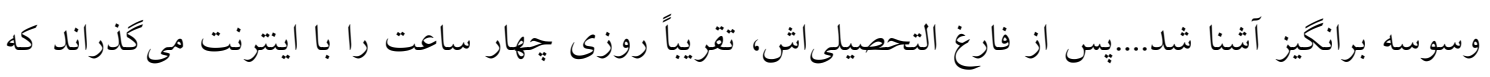


البته 99 درصد زمانش با برنامههاى مختلف جت مانند ياهو جت، ماكروسافت، AOL MIRC ICQ مى

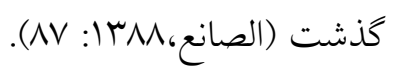

الصانع قصد دارد از محدوديتها و سختخيرىهاى جامعلى سعودى براى زنان سخن بخويد. در واقع سنت-

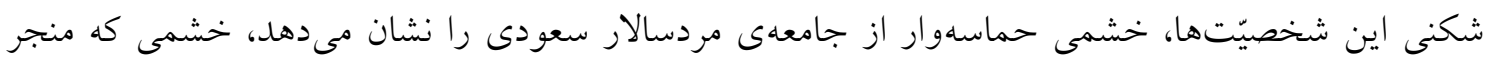
مى گردد زن به رفتارهايى دست بزند كه شكست و سرخورد كى را با خود به همراه خواهد داشت.

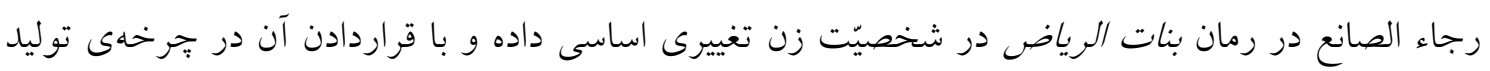

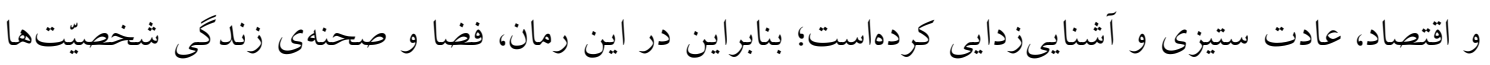
از خانه تا عرصههاى اجتماعى دكركون شده و متناسب با اين تحول، شخصيّتهاى داستان نيز از انفعال

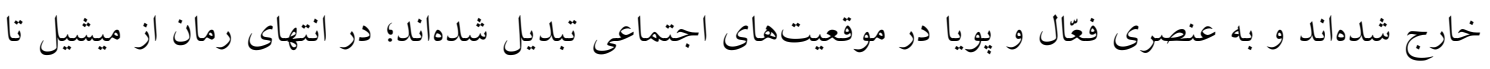
المّ نوير و قمره، همكى زنانى شاغل هستند كه نيازهاى اقتصادى خانه را تأمين مى كنند. نويسنده با ترسيم

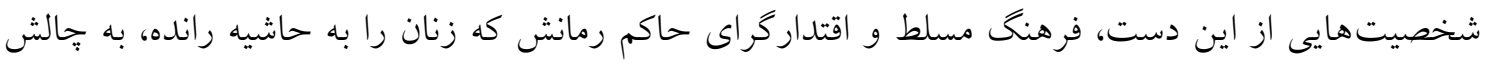
مى كشد. در رمان بنات الرياض، نكتهى شاخص اين است كه ما با دنيايى روبه روييم كه شايد تا قبل از اين به ندرت

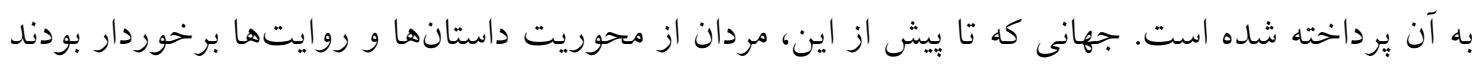

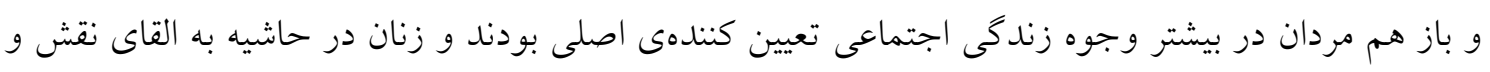
وظايف كليشهاى مى برداختند، اما در جهانى كه نويسنده در اين رمان خلق كرده، زنان، ديخر اشخاصى فد فداكار كه تمام وجودشان را وقف اعضاى خانواده مىكنند، تصوير نمىشوند، زنان اين آثار از يوستهى نقشهاى سنتى بيرون مى آيند و بيشتر فضايى كه شخصيت ها در آن حضور دارند خارج از محدودهى خانه است.

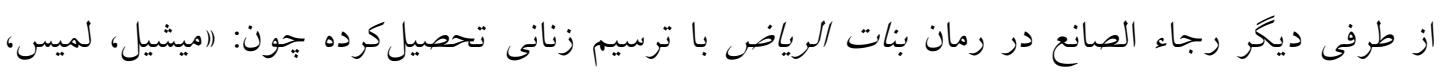

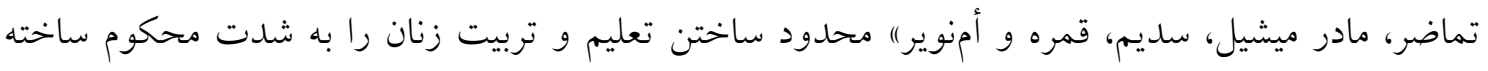

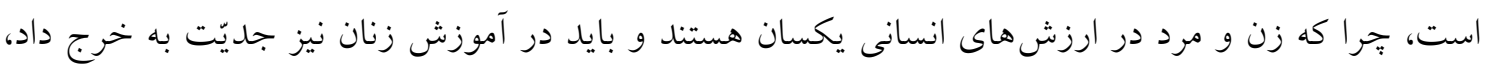

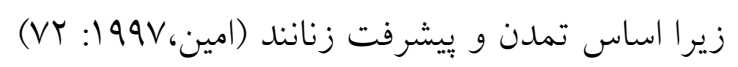

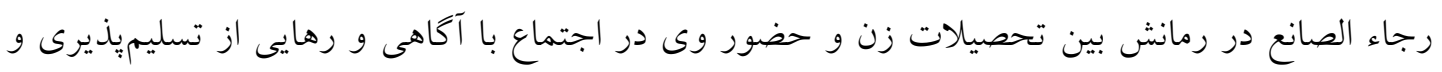

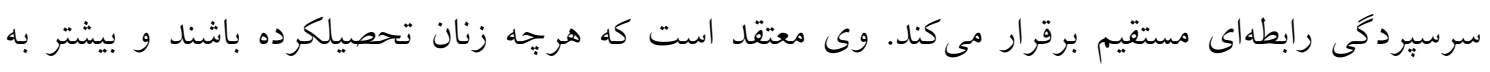

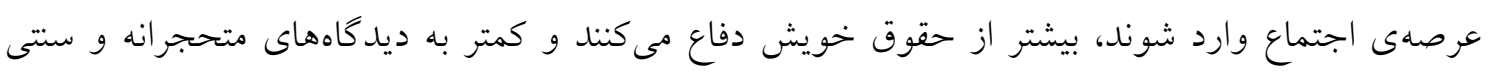

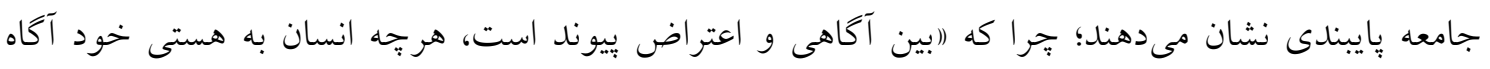
باشد، نخرانى وى، نسبت به هستىاش، بيشتر و در نتيجه ايستادكى او در برابر نيروهايى كه مى كوشند اين

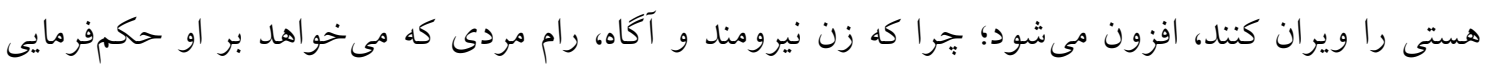

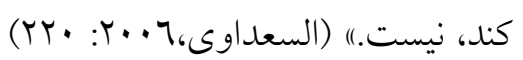




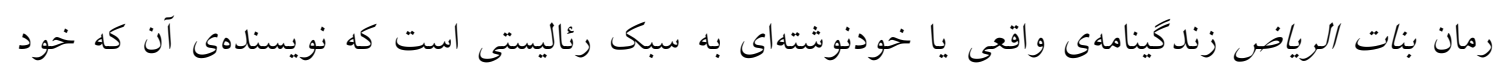

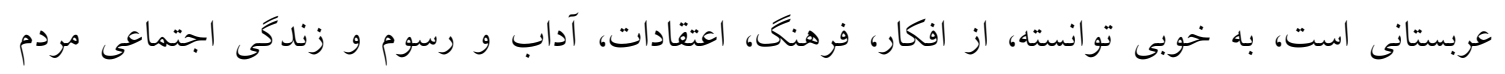

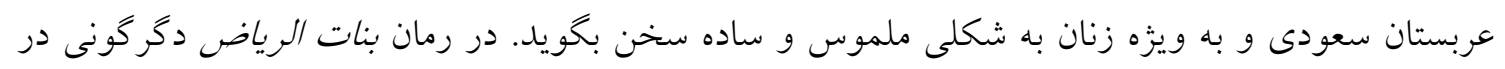

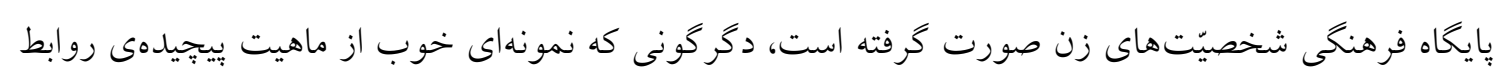

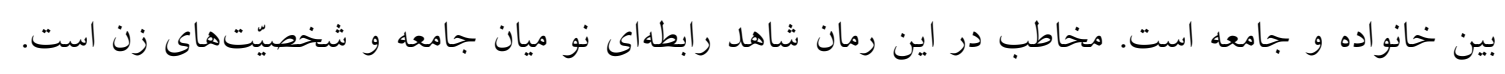

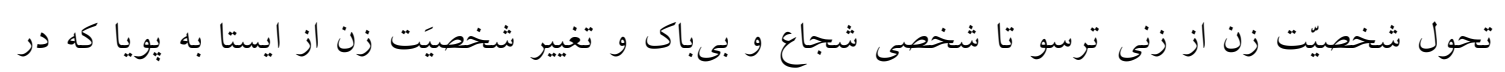

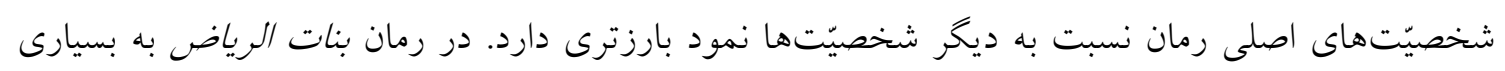

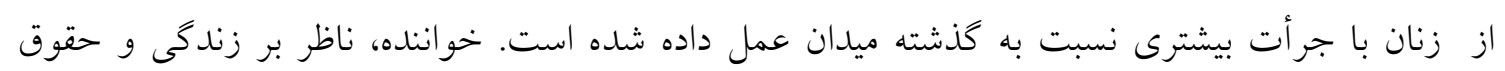

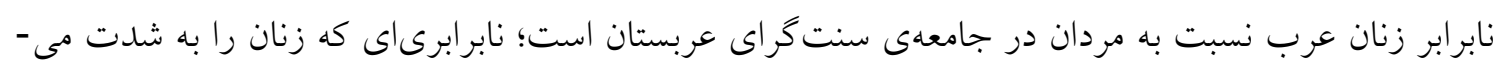

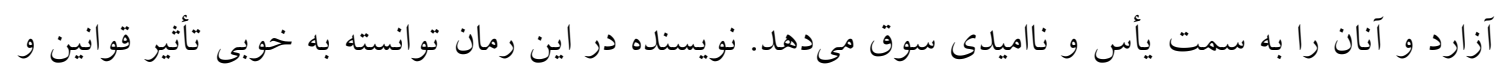

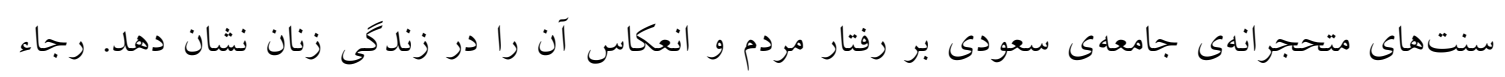

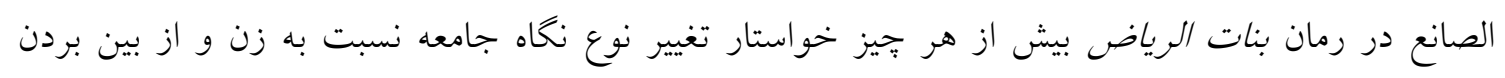

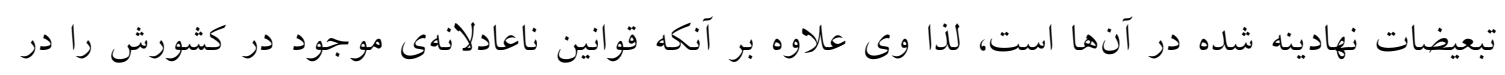

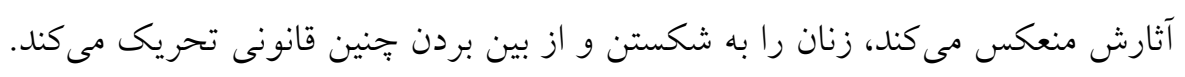

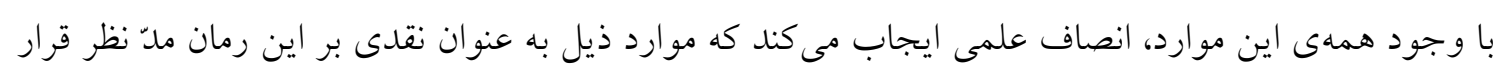
كيرد:

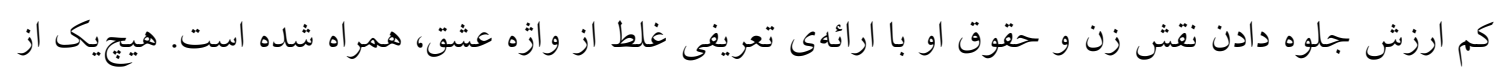

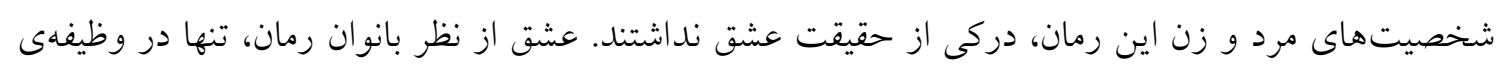

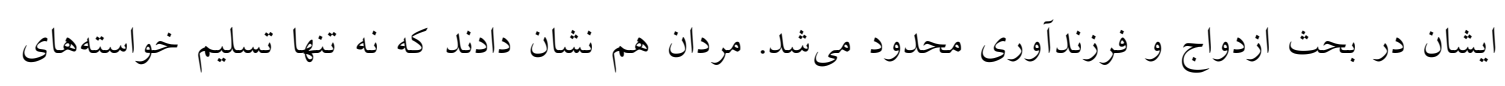

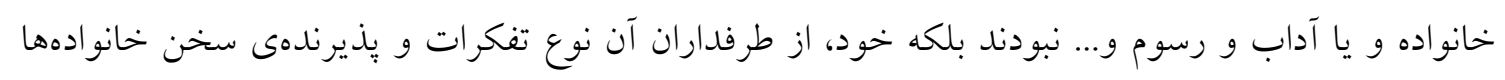

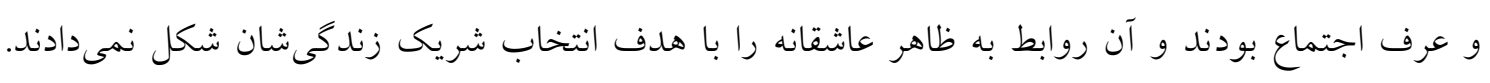

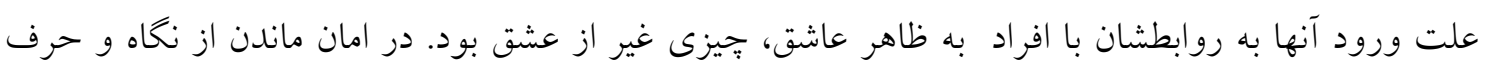

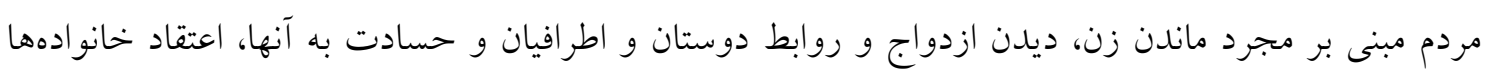

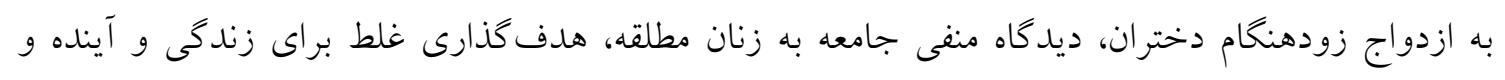

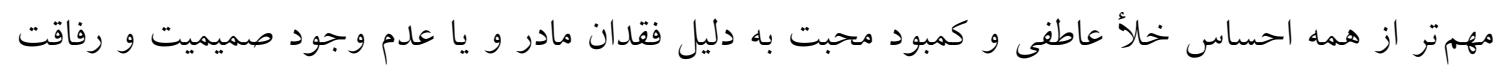

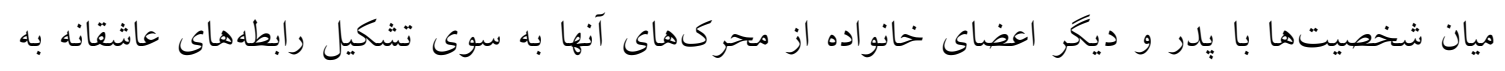

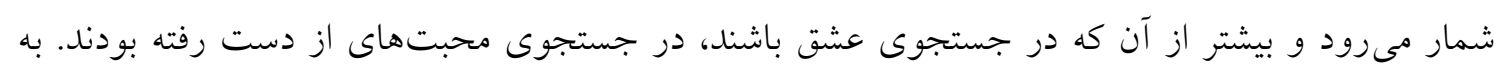

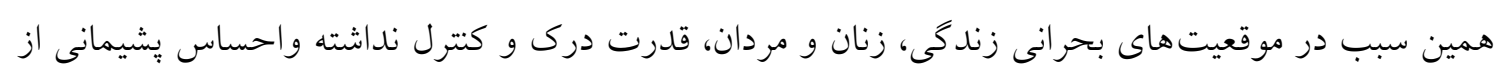
انتخاب خود و ازدواج، موجب شكست رابطهها مى شئد. 
نويسنده در اين رمان با تعميم خصوصيات جهار تيٍ شخصيتى مشابه از قشر مرفه جامعه به همه دختران رياض، در واقع ديخر دختران عربستان را كه زندكى خود را وقف تثبيت جايعاه والاى زن در جامعه كرده و

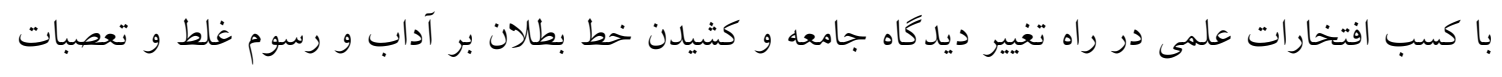

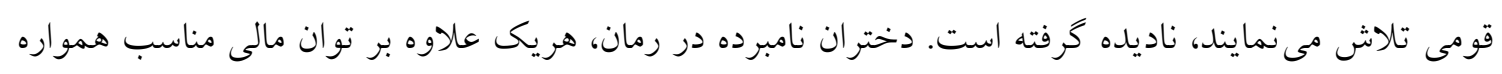

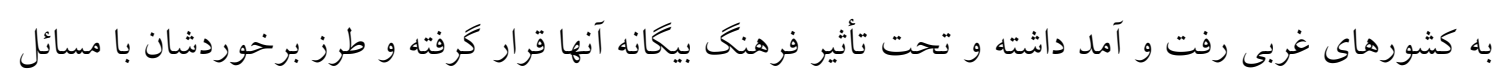

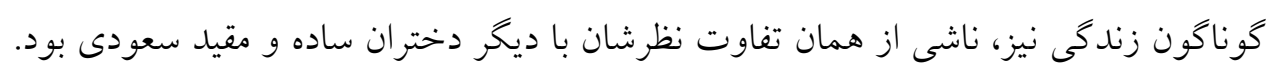

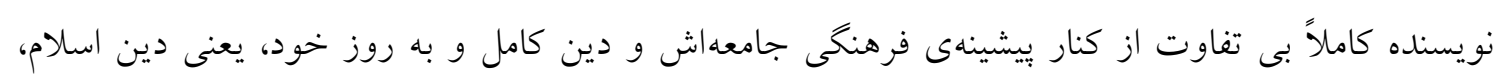

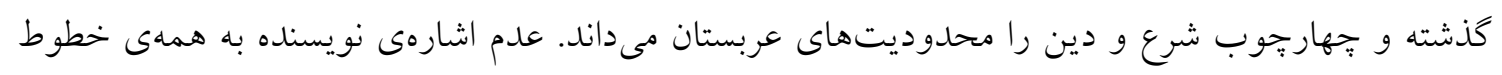

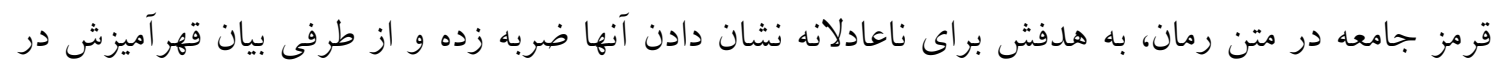

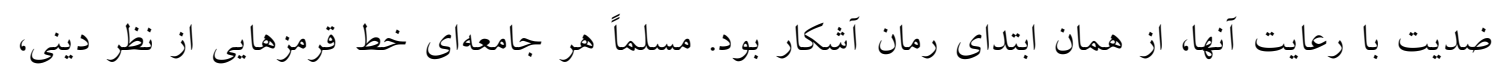
سياسى، اخلاقى و اجتماعى براى خود تعريف مى كند كه همه افراد جامعه ديدكاهى مشابه به آنها ندارند.

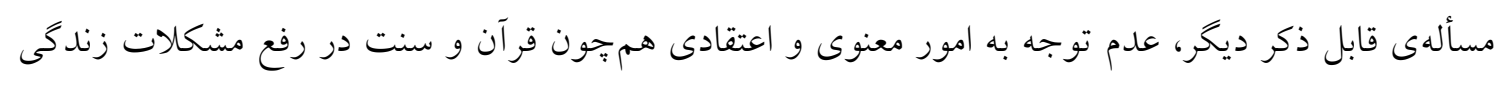
است. در جاى جاى داستان، شخصيتها همواره در موقعيتهاى كوناكون سراغ فال و طالع بينى رفته و يا وناي

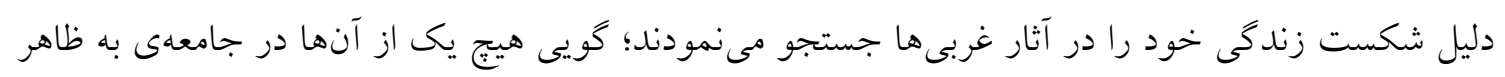

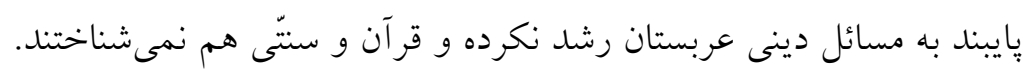

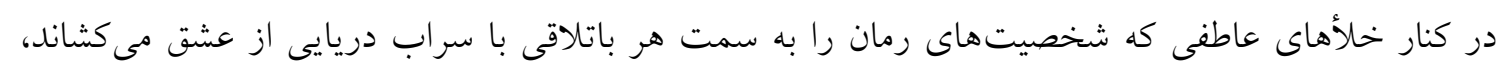

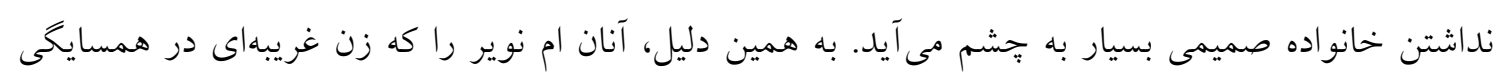

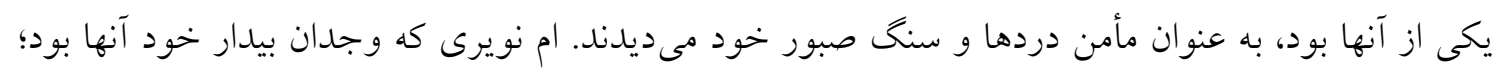

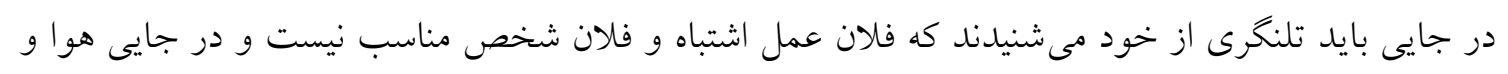

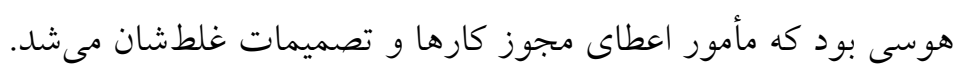




$$
\text { فهرست منابع ومآخذ: }
$$

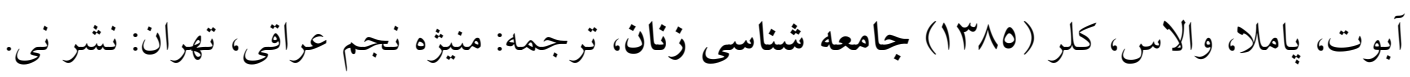
امين، قاسم(99 (19): الأعمال الكاملة، تحقيق محمد عماره، مصر : دارالشرق. خسرويناه، عبدالحسين(1) (1) : تبيين و تحليل فمنيسم، تهر ان: طهورا.

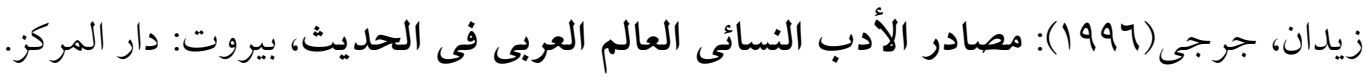

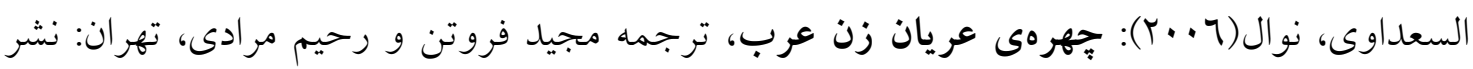

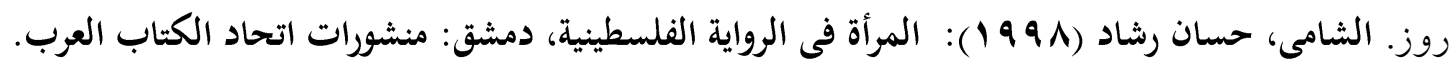

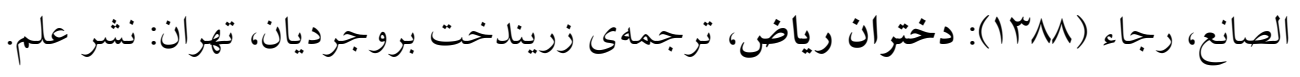

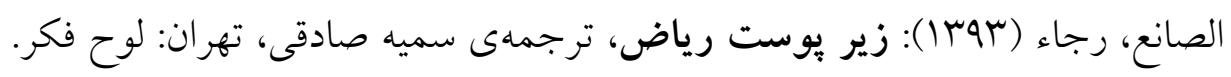

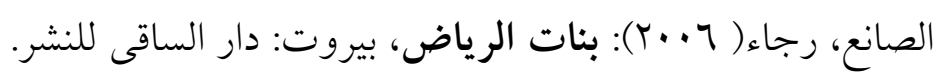

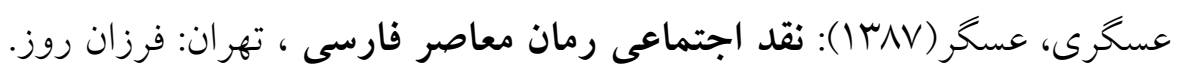

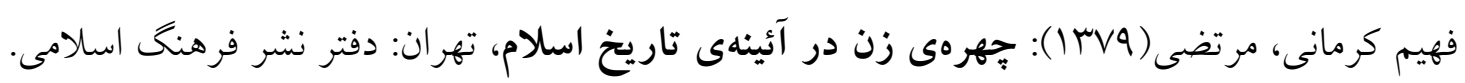

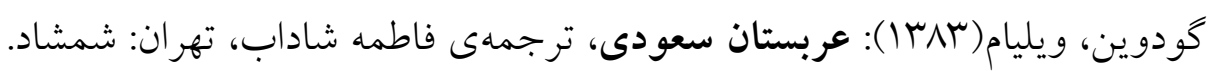

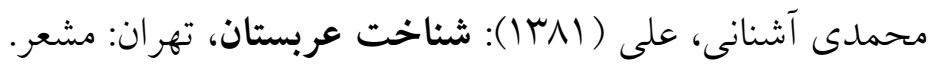

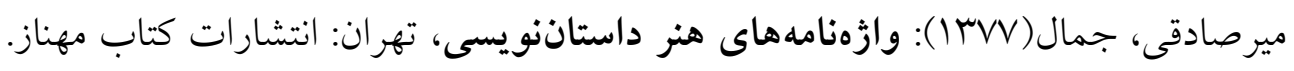
وادى، طه( (9V1): صورة المرأة فى الرواية المعاصرة، القاهرة: مركز كتب الشرق الأوسط.

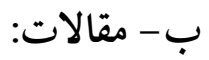

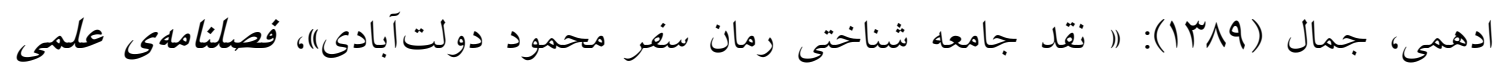

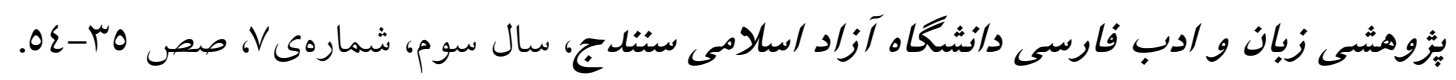

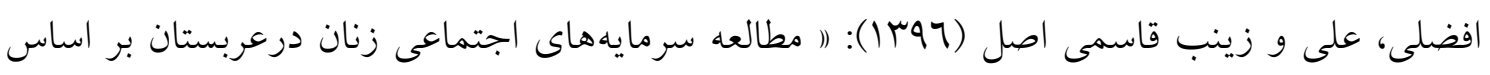

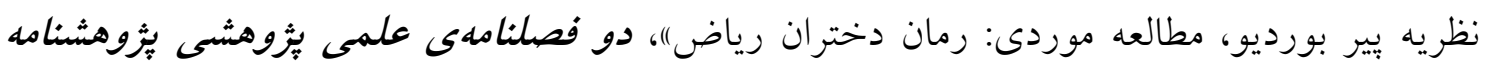

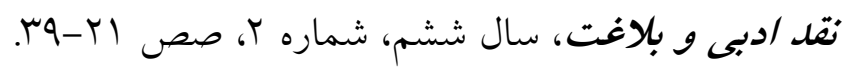

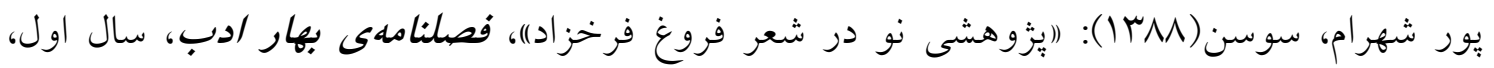

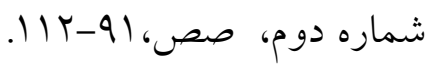


الجمعان، سامى عبداللطيف(ه ( ؟ ؟): 》 مقصدية إنتاج الخطاب وتلقيه خطاب: الرواية النسائية السعودية

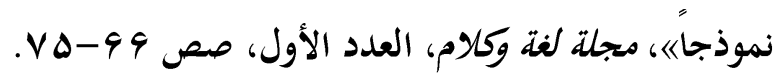

حسينى، شكوهالسادات(90ب(): ( زبان و جنسيت در رمان ذاكرة الجسل نوشته احلام مستغانمى")،

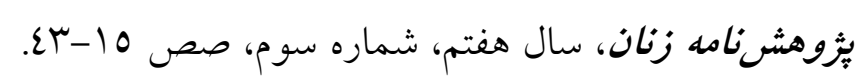

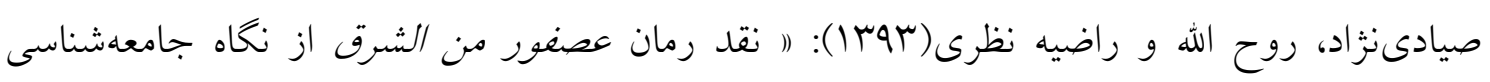

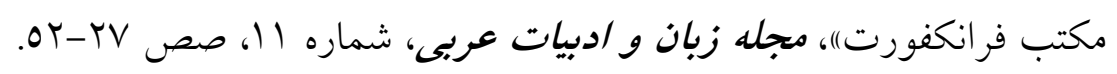
عبداللهى، حسن و اميد ايزانلو (1) (1): (ا تحليل جامعهشناختى رمان زقاق الماق از نجيب محفوظ)، يثزوهشنامهى نقد ادب عربي، شماره ع، صص 0 • 1-7 I ا.

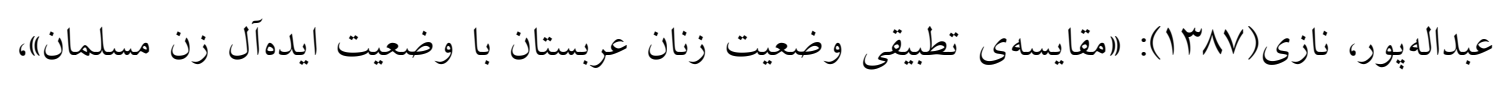
مجلهى زن و مطالعات خانو/ده، سال اول، شمارهى اول. صص

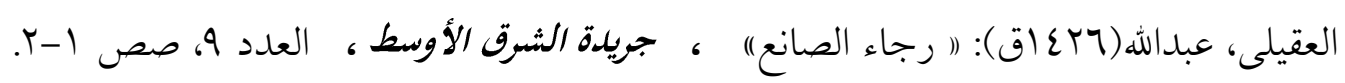
ملابراهيمى، عزت و صغرى رحيمى(90ب1): (ا نقد جامعهشناختى رمان صيادون فى شارع ضيق از

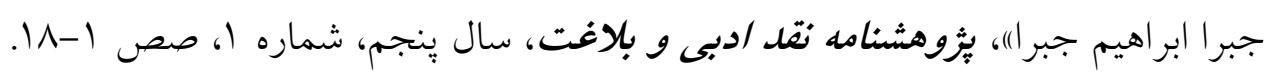
ملابراهيمى، عزت و على صباغيان(سوب(1): (ا نقد جامعهشناسى رمانهاى سه گانه احلام مستغانمى")،

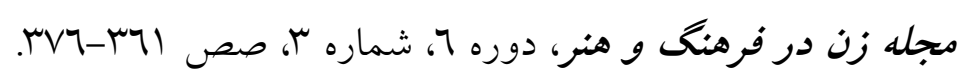
منصور، آمال(ه | †): 》 الكتابة الأنثوية العربية فى بنات الرياض: من العنف الأسرى حتى تهشيم النسق

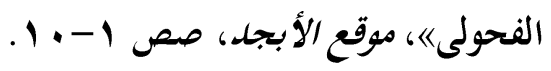




\section{List of references:}

\section{A - Book:}

- Abbot, Pamela, Wallace, Clare (2006) Women's Sociology, Translated by: Manijeh Najm Araghi, Tehran: Nayer Ney.

- Amin, Qassim (1997): Al-Aqal al-Kamelah, Research by Mohammed Amara, Egypt: Dar eshragh.

- Khosrowpanah, Abdolhossein (2009): Explaining Feminism, Tehran: Tahoura. Zidane,

- Gurji (1996): Mosad al-'Adb al-Nassayi al-Alam al-Arabi al-Hadith, Beirut: Dar Center.

- Al-Saadawi, Nawal (2006): Arab Female Nude Face, Translated by Majid Foroutan and

- Rahim Moradi, Tehran: Publishing the Day. Al-Shami, Hassan Rashad (1998): Al-Ma'rafi al-Rawa'ah al-Ful'estine, Damascus: the laws of the Almighty Allah.

- Al-Sana'a, Raja (2009): Girls in Riyadh, translated by Zarrindekt Boroujerdiyan, Tehran: Nazar Alam.

- Al-Sana'a, Raja (1393): Under the skin of Riyadh, translated by Somayeh Sadeghi, Tehran: Thoughts of Thought.

- Al-Sana'a, Raja (2006): Banat Al-Riyad, Beirut: Dar al-Saqi llnshir.

- Asgari, Asgar (2008): The Social Criticism of Contemporary Persian Farsi, Tehran: Farzan Rooz.

- Fahim Kermani, Morteza (2000): Woman's Face in the Mirror of Islamic History, Tehran: Islamic Culture Publishing Office.

- Goodwin, William (2004): Saudi Arabia, Fatima Shadab translation, Tehran: Shamshad. Mohammadi Ashnani, Ali (2002): Recognition of Saudi Arabia, Tehran: Meshehr.

- Mirasadeghi, Jamal (1998): Dictionary of Art Writing, Tehran: Mahnaz Book Publishing.

- Wadi, Taha (1971): The Book of Almighty, Al-Qaherah: The Center for the Literature of the East. 


\section{B-Articles:}

- Adhamami, Jamal (2010): "Sociological Criticism of Mahmoud Dawab-Abadi's Travel novel", Ph.D. Journal of Persian Language and Literature, Islamic Azad University, Sanandaj, Third Year, Issue 7, Pages 35-54.

- Afzali, Ali and Zeinab Ghasemi-Asl (1396): "Study of women's social capital in Iraq based on Pierre Bourdieu's theory, Case study: The novel of Riyadh girls", Two scientific journals, Literary criticism and rhetoric research journal, Year 6, No. 2, Pages 21-39.

- Pour Shahram, Susan (2009): "A New Research in Forough Farrokhzad Poetry", Spring Quarterly Journal, First Year, No. 2, pp. 91-112.

- Al-Jamaan, Sami Abdul Latif (2015): "The Purpose of the Invention of AlKhattab and Al-Taqiyah Addressed: Al-Rawiya Al-Nassa'ī-ye Al-Sa'diyat Nemozja", Magl. Words and Words, Al-Nid Al-Awl, pp. 66-75.

- Hosseini, Shokouh-al-Sadat (1395): "Language and Sex in the Book of Zakrara Al-Juds by Ahlam Mostahnami", Women's Research Paper, seventh year, No. 3, pp. 15-43.

- Sayadi-Nejad, Ruhollah and Razieh Nazari (1393): "A Critique of the Novel of Asfour I Al-Sharq from the Viewpoint of the School of Sociology of Frankfurt," Arabic Language and Literature, issue 11, pp. 27-52.

- Abdollahi, Hassan and Omid Isanlou (2012): "The Sociological Analysis of Zaghagh Al-Mizdg's Novel from Najib Mahfouz", Arabic Literature Review Review, No. 4, pp. 105-126.

- Abdollah Poor, Nazi (2008): "A Comparative Comparison of the Status of Saudi Women with the Status of an Ideal Muslim Woman", Women's Magazine and Family Studies, First Year, First Issue. Pages 125-151.

- Al-Aqili, Abdullah (1426 AH): "Raja al-Sana'a", Jiridat al-Sharq al-'Aust, al'Add 9, pp. 1-2.

- Mulla Ebrahimi, Ezzat and Soghra Rahimi (1395): "The Sociological Criticism of the Sayadoon Fay Shar'a's Disappearance from Jabra Ibrahim Jabra", Literary Criticism and Rhetoric, Vol. 5, No. 1, pp. 1-18.

- Mulla Ebrahimi, Ezzat and Ali Sabaghian (1393): "The Critique of Sociology of Trivial Novels by Ahlam Motahanemi", Journal of Women in Culture and Arts, Vol. 6, No. 3, Pages 361-376.

- Mansour, Amal (2015): " The Arab Feminist Kubba in the Girls of Riyadh: From Domestic Violence to Chaem Al-Fashoulo Format ", Adjad Website, Pages 1-10. 